\title{
Influence of the dietary protein:lipid ratio and fish oil substitution on fatty acid composition and metabolism of Atlantic salmon (Salmo salar) reared at high water temperatures
}

\author{
Vasileios Karalazos ${ }^{1}$, Eldar Å. Bendiksen ${ }^{2}$, James R. Dick ${ }^{1}$, Douglas R. Tocher ${ }^{1}$ and John Gordon Bell ${ }^{1 *}$ \\ ${ }^{1}$ Institute of Aquaculture, University of Stirling, Stirling FK9 4LA, Scotland, UK \\ ${ }^{2}$ BioMar AS, Nordre Gate 11, N-7484 Trondheim, Norway \\ (Received 23 July 2010 - Revised 7 October 2010-Accepted 12 October 2010-First published online 17 December 2010)
}

\begin{abstract}
A factorial, two-way, experimental design was used for this 10-week nutritional trial, aiming to elucidate the interactive effects of decreasing dietary protein:lipid level and substitution of fish oil (FO) with rapeseed oil (RO) on tissue fatty acid (FA) composition and metabolism of large Atlantic salmon (Salmo salar L.) reared at high water temperatures (sub-optimal, summer temperatures: $11 \cdot 6^{\circ} \mathrm{C}$ ). The six experimental diets were isoenergetic and formulated to include either FO or RO (60\% of the added oil) at three dietary protein:lipid levels, specifically (1) $350 \mathrm{~g} / \mathrm{kg}$ protein and $350 \mathrm{~g} / \mathrm{kg}$ lipid, (2) $330 \mathrm{~g} / \mathrm{kg}$ protein and $360 \mathrm{~g} / \mathrm{kg}$ lipid, (3) $290 \mathrm{~g} / \mathrm{kg}$ protein and $380 \mathrm{~g} / \mathrm{kg}$ lipid. Final weight, specific growth rate and thermal growth coefficient were positively affected by the dietary RO inclusion at the expense of FO, while no significant effects were seen on growth due to the decreasing protein level. The oil source had a significant effect on muscle and liver FA composition. However, the changes in muscle and liver FA indicate selective utilisation or retention of individual FA and moderate reductions in tissue EPA and DHA. Pyloric caeca phospholipid FA composition was significantly affected by the two factors and, in some cases, significant interactions were also revealed. Liver and red muscle $\beta$-oxidation capacities were significantly increased due to $\mathrm{RO}$ inclusion, while an interactive effect of protein level and oil source was shown for white muscle $\beta$-oxidation capacity. The results could explain, at least partially, the better performance that was shown for the RO groups and the enhanced protein-sparing effect.
\end{abstract}

Key words: Atlantic salmon: Rapeseed oil: PUFA: $\beta$-Oxidation

In recent years, one of the main research topics in aquaculture nutrition has been the replacement of fishmeals (FM) and fish oils (FO) in the diets for fish exploiting alternative sources for protein and lipid, respectively. The use of FM and FO in fish nutrition, especially in the intensive culture of carnivorous species such as Atlantic salmon (Salmo salar), has been a common practice for years and, to a great extent, still is today. This is because they constitute excellent sources of essential amino acids and fatty acids (FA), and especially of highly unsaturated $\mathrm{FA}^{(1-3)}$. However, the need for reduction in the consumption of these commodities in aqua feeds is required for a number of reasons, including environmental and economic concerns, including sustainability issues, price increases, etc. ${ }^{(4-8)}$. In addition, there are issues regarding the quality of the final product, as there is a potential risk of contamination of FM and $\mathrm{FO}$ with organic pollutants ${ }^{(9-13)}$.

Numerous commodities have been successfully tested as alternatives to FM and FO. In the case of FO replacement, vegetable oils (VO), including rapeseed oil (RO), have been included, either as single replacements or as part of VO blends. The effects of such dietary alterations have been recently reviewed ${ }^{(13-15)}$ and can be summarised as causing no detrimental effects on growth and feed utilisation $^{(16-22)}$ or notably, in some cases, enhancing growth $^{(21,23,24)}$. However, the dietary inclusion of $\mathrm{RO}$ at the expense of FO leads to significant changes in tissue FA compositions, which reflect the FA compositions of the diets, and FA metabolism, including $\beta$-oxidation. It should be noted that RO's content of $18: 2 n-6$ and $18: 3 n-3$ is moderate and at a ratio of $2: 1$, and thus should result only in modest deposition of these FA in fish tissues and, perhaps, enhance the endogenous conversion of $18: 3 n-3$ to $20: 5 n-3$ and $22: 6 n-3$. Also, RO contains high levels of MUFA, especially 18:1n-9, which are preferred substrates for energy production by Atlantic salmon, and hence growth rates of the fish should not be

Abbreviations: FA, fatty acid; FCR, feed conversion ratio; FM, fishmeal; FO, fish oil; HP, high protein; LP, low protein; MP, medium protein; PL, phospholipid; PPV, protein productive value; RO, rapeseed oil; VO, vegetable oil.

*Corresponding author: Professor J. G. Bell, fax +44 1786 472133, email g.j.bell@stir.ac.uk 
compromised $^{(16,25-27)}$. Alterations of the fish tissue FA profile are of importance given the role of highly unsaturated FA, and especially EPA and DHA, to human health and the increasing demand of consumers for nutritious and health-promoting products ${ }^{(13)}$. Fish are unique sources of these FA, and hence their nutritional characteristics should not be compromised.

However, there are issues regarding FM and FO replacement in fish diets, which remain unclear. For instance, the authors of the aforementioned reviews have pointed out that the simultaneous reduction of both FM and FO could be challenging due to the expected reduction in essential FA and amino acids.

In those terms, the investigation of the replacement of FO with a VO such as RO with a concurrent reduction of $\mathrm{FM}$ is of considerable interest. The use of energy-dense diets can be a potentially useful approach towards the reduction of FM, as such diet formulations require less rotein by exploiting lipids for energy production, and hence can be potentially advantageous for the nutrition of carnivorous species, such as Atlantic salmon ${ }^{(28,29)}$. Research findings agree that these diets are performing well in terms of fish growth and feed utilisation, while a sparing effect on protein by increased dietary oil has also been shown ${ }^{(23,24,30-34)}$. However, in most of these studies, relatively high dietary protein:lipid levels were used and, hence, how much protein reduction can occur, without performance loss, still needs to be elucidated. Moreover, the dietary protein:lipid content and the FO replacement with RO affect tissue FA composition and FA metabolism, including catabolism via $\beta$-oxidation which influences fish growth, while other interactions may also occur ${ }^{(14,23,24,35)}$.

In an earlier trial, we investigated the interactive effects of the dietary protein:lipid ratio and the inclusion of RO at the expense of $\mathrm{FO}$ in the diets of salmon in cold (winter) water temperatures ${ }^{(24)}$. The results of that study showed a positive effect on fish growth, as well as a protein-sparing effect but also changes in tissue FA composition. Given that water temperature is a key factor in fish nutrition and FA retention and metabolism ${ }^{(36)}$, the impact of even lower dietary protein:lipid ratios and different lipid sources in Atlantic salmon reared at high (sub-optimal, summer temperatures) water temperatures is of considerable interest. Moreover, the positive effects of RO inclusion on growth have been associated with changes in the digestibility of FA. The uptake and digestibility of lipids and ultimately the utilisation of diets could be affected by the intestinal phospholipid (PL) FA composition and the consequent alterations occurring due to dietary FA changes, especially when high-lipid diets are used. It should be noted that the interactive effects of the dietary protein:lipid level and RO inclusion on growth, feed utilisation, nutrient and FA digestibility and whole-body chemical composition of large Atlantic salmon ( $S$. salar L.) that are shown in the present paper were presented and discussed in detail in Karalazos et al. ${ }^{(37)}$.
Hence, the aim of the present study was to elucidate the interactive effects of $\mathrm{FO}$ replacement with $\mathrm{RO}$ at various dietary protein:lipid ratios on tissue FA compositions and metabolism, including FA $\beta$-oxidation and PL FA compositions of the pyloric caeca, of large Atlantic salmon at high water temperatures.

\section{Materials and methods}

\section{Fish and facilities}

The 10-week feeding trial was carried out at the Fjord Research Station AS (Helgeland, Dønna, Norway, $66^{\circ} \mathrm{N}$ ) using Atlantic salmon ( $S$. salar) of an initial mean weight of $2053 \mathrm{~g}$. Eighteen sea cages of $125 \mathrm{~m}^{3}(5 \times 5 \times 5 \mathrm{~m})$ were used with approximately ninety-three fish randomly distributed in each cage. Before the experiment, the fish were acclimatised to the trial cages for $63 \mathrm{~d}$ at $12^{\circ} \mathrm{C}$, being fed a commercial diet from BioMar AS $(9 \mathrm{~mm}$; $360 \mathrm{~g} / \mathrm{kg}$ protein and $350 \mathrm{~g} / \mathrm{kg}$ fat). During the experimental period, the average water temperature was $11.6 \pm 1 \cdot 1^{\circ} \mathrm{C}$ and the salinity was 32.5 (SD 0.4 ) g/l, while the fish were subjected to a natural photoperiod. Mortalities were recorded and dead fish were removed daily. Experimental procedures complied with the Norwegian code of practice for the care and use of animals for scientific purposes. There are no aspects of this trial that would cause aggravated or unnecessary harm or stress to the fish involved.

\section{Experimental diets and feeding}

Following a factorial (two-way $3 \times 2$ ) experimental design, six diets were formulated at three different dietary protein/fat levels and two different levels of FO substitution. Regarding protein/lipid levels, the diets contained either: (1) $350 \mathrm{~g} / \mathrm{kg}$ protein and $350 \mathrm{~g} / \mathrm{kg}$ lipid (high protein; HP); (2) $330 \mathrm{~g} / \mathrm{kg}$ protein and $360 \mathrm{~g} / \mathrm{kg}$ lipid (medium protein; MP); (3) $290 \mathrm{~g} / \mathrm{kg}$ protein and $380 \mathrm{~g} / \mathrm{kg}$ lipid (low protein; LP). For the oil source, FO or RO was used within each dietary protein:fat level, where crude RO comprised $60 \%$ of the total added oil in the RO diets, the remainder being FO. All diets were isoenergetic (gross energy $25 \mathrm{~kJ} / \mathrm{g}$ ). The diets were formulated to meet all known nutritional requirements of salmonid fish ${ }^{(3)}$ and were produced as practical-type extruded pellets $(9 \mathrm{~mm})$ at the BioMar TechCentre (Brande, Denmark). The ingredients, proximate and FA compositions of the experimental diets are shown in Tables 1 and 2, respectively. Feeding was carried out by hand to satiation on a daily basis, including two daily meals with a minimum of $4 \mathrm{~h}$ between them. A lift-up system was used to collect uneaten feed, which was recorded for accurate calculations of feed intake and feed conversion ratio (FCR). 
Table 1. Diet formulations, proximate compositions $(\mathrm{g} / \mathrm{kg})$ and energy content $(\mathrm{kJ} / \mathrm{g})$ of the six experimental diets fed to Atlantic salmon (Salmo salar L.) for 10 weeks

\begin{tabular}{lcccccc}
\hline & HP-FO & MP-FO & LP-FO & HP-RO & MP-RO & LP-RO \\
\hline Components (g/kg) & & & & & & \\
$\quad$ Fishmeal* & 402 & 340 & 268 & 402 & 340 & 268 \\
$\quad$ Oilseed and legume seed meals & 181 & 190 & 190 & 181 & 190 & 190 \\
$\quad$ Binder & 135 & 130 & 190 & 135 & 130 & 190 \\
Fish oil & 304 & 330 & 351 & 122 & 132 & 141 \\
$\quad$ Rapeseed oilt & 0 & 0 & 0 & 182 & 198 & 211 \\
$\quad$ Premixesł & 9 & 10 & 11 & 9 & 10 & 11 \\
Compositions (g/kg) & & & & & & \\
$\quad$ Moisture & 49 & 69 & 69 & 51 & 73 & 67 \\
DM & 951 & 931 & 931 & 949 & 927 & 933 \\
Protein & 353 & 338 & 291 & 345 & 328 & 296 \\
$\quad$ Lipid & 350 & 349 & 386 & 351 & 368 & 382 \\
$\quad$ Ash & 81 & 75 & 63 & 79 & 73 & 63 \\
Gross energy (kJ/g) & $25 \cdot 25$ & $25 \cdot 22$ & $25 \cdot 32$ & $25 \cdot 47$ & $25 \cdot 41$ & $25 \cdot 36$ \\
$\quad$ DP:DE & $15 \cdot 4$ & $14 \cdot 0$ & $12 \cdot 3$ & 13.7 & $13 \cdot 0$ & $12 \cdot 3$ \\
\hline
\end{tabular}

HP-FO, high-protein fish oil; MP-FO, medium-protein fish oil; LP-FO, low-protein fish oil; HP-RO, high-protein rapeseed oil; MP-RO, medium-protein rapeseed oil; LP-RO, low-protein rapeseed oil; DP, digestible protein; DE, digestible energy.

* South American, Anchoveta oil.

†European, non-GM, double-low-quality rapeseed oil.

$\ddagger$ Vitamin and mineral premixes prepared according to the BioMar AS commercial standards, which include crystalline amino acids and Carophyll pink to provide $40 \mathrm{mg} / \mathrm{kg}$ astaxanthin (DSM Roche, Basel, Switzerland).

\section{Sampling procedure}

At the start of the trial, the fish were bulk weighed. At the end (10th week), the fish were individually weighed after being anaesthetised in MS-222 (metacain, $8 \mathrm{mg} / \mathrm{l}$ ). At the end of the trial, another three fish/cage were sampled at random for lipid and FA composition of muscle, liver and pyloric caeca PL and for $\beta$-oxidation determination. Fish were killed with a sharp blow to the head, and samples of the liver and pyloric caeca were dissected and immediately frozen in liquid $\mathrm{N}_{2}$. Muscle samples, representative

Table 2. Fatty acid compositions ( $\mathrm{g} / 100 \mathrm{~g}$ total fatty acids) of the six experimental diets fed to Atlantic salmon (Salmo salar L.) for 10 weeks

\begin{tabular}{|c|c|c|c|c|c|c|}
\hline & HP-FO & MP-FO & LP-FO & HP-RO & MP-RO & LP-RO \\
\hline \multicolumn{7}{|l|}{ Fatty acids } \\
\hline $14: 0$ & $8 \cdot 8$ & 8.5 & $8 \cdot 3$ & 3.4 & $3 \cdot 0$ & $2 \cdot 8$ \\
\hline $16: 0$ & $23 \cdot 2$ & $20 \cdot 3$ & $20 \cdot 2$ & $12 \cdot 1$ & $10 \cdot 9$ & $10 \cdot 2$ \\
\hline $18: 0$ & 5.9 & 4.9 & $5 \cdot 0$ & $3 \cdot 8$ & $4 \cdot 3$ & 3.5 \\
\hline $20: 0$ & 0.6 & 0.5 & 0.5 & 0.7 & 0.8 & 0.7 \\
\hline $22: 0$ & 1.3 & 1.2 & $1 \cdot 2$ & 1.9 & 2.5 & 1.7 \\
\hline Total saturates* & $40 \cdot 4$ & 35.9 & $35 \cdot 7$ & $22 \cdot 0$ & 21.7 & $19 \cdot 1$ \\
\hline $16: 1 n-7$ & 8.0 & 8.8 & 8.7 & $3 \cdot 3$ & 3.1 & 3.0 \\
\hline $18: 1 n-9$ & 9.5 & $10 \cdot 9$ & $11 \cdot 3$ & $37 \cdot 7$ & $37 \cdot 7$ & $40 \cdot 0$ \\
\hline $18: 1 n-7$ & $3 \cdot 2$ & 3.3 & 3.4 & $3 \cdot 7$ & 3.0 & 3.1 \\
\hline $20: 1 n-9$ & 1.5 & 1.4 & 1.3 & 1.6 & 1.5 & 1.5 \\
\hline $22: 1$ & $1 \cdot 7$ & 1.7 & 1.5 & 1.3 & $1 \cdot 1$ & 0.9 \\
\hline $24: 1 n-9$ & 0.5 & 0.5 & 0.6 & 0.4 & 0.4 & 0.3 \\
\hline Total monoenes $\dagger$ & $24 \cdot 7$ & $26 \cdot 8$ & $27 \cdot 0$ & $47 \cdot 9$ & $47 \cdot 1$ & $49 \cdot 1$ \\
\hline $18: 2 n-6$ & $2 \cdot 1$ & $2 \cdot 4$ & $2 \cdot 7$ & $12 \cdot 5$ & $13 \cdot 0$ & $13 \cdot 8$ \\
\hline $20: 2 n-6$ & 0.1 & 0.2 & 0.2 & 0.1 & 0.1 & 0.1 \\
\hline $20: 4 n-6$ & $1 \cdot 1$ & $1 \cdot 1$ & $1 \cdot 1$ & 0.4 & 0.5 & 0.4 \\
\hline $22: 5 n-6$ & 0.3 & 0.3 & 0.3 & 0.1 & 0.1 & 0.1 \\
\hline Total $n-6 \ddagger$ & $4 \cdot 1$ & 4.6 & 4.8 & $13 \cdot 2$ & $14 \cdot 0$ & 14.8 \\
\hline $18: 3 n-3$ & 0.6 & 0.7 & 0.8 & $6 \cdot 2$ & $6 \cdot 3$ & 6.7 \\
\hline $18: 4 n-3$ & $2 \cdot 1$ & $2 \cdot 3$ & $2 \cdot 2$ & 0.8 & 0.8 & 0.7 \\
\hline $20: 4 n-3$ & 0.6 & 0.7 & 0.6 & 0.2 & 0.2 & 0.2 \\
\hline $20: 5 n-3$ & $17 \cdot 6$ & $19 \cdot 0$ & $18 \cdot 8$ & $5 \cdot 8$ & $6 \cdot 0$ & $5 \cdot 8$ \\
\hline $22: 5 n-3$ & 1.9 & $2 \cdot 0$ & $2 \cdot 0$ & 0.7 & 0.7 & 0.6 \\
\hline $22: 6 n-3$ & 8.0 & 8.0 & $7 \cdot 9$ & $3 \cdot 2$ & $3 \cdot 2$ & 3.0 \\
\hline Total $n-3 \S$ & $30 \cdot 8$ & $32 \cdot 7$ & 32.5 & $16 \cdot 9$ & $17 \cdot 3$ & $17 \cdot 1$ \\
\hline Total PUFA & 34.9 & $37 \cdot 3$ & $37 \cdot 3$ & $30 \cdot 1$ & $31 \cdot 3$ & 31.9 \\
\hline$n-3: n-6$ & 7.5 & $7 \cdot 1$ & $6 \cdot 8$ & 1.3 & 1.2 & 1.2 \\
\hline
\end{tabular}

HP-FO, high-protein fish oil; MP-FO, medium-protein fish oil; LP-FO, low-protein fish oil; HP-RO, highprotein rapeseed oil; MP-RO, medium-protein rapeseed oil; LP-RO, low-protein rapeseed oil.

* Includes 15:0

†Includes $16: 1 n-9$ and $20: 1 n-7$.

$\ddagger$ Includes 18:3n-6, 20:3n-6 and $22: 4 n-6$.

§Includes $20: 3 n-3$ and $22: 4 n-3$. 
of the edible portion, were obtained by cutting a steak between the dorsal and ventral fins (Norwegian Quality Cut), which were then skinned, deboned and homogenised. For $\beta$-oxidation determination, samples of liver, red and white muscle were taken separately and immediately frozen in liquid $\mathrm{N}_{2}$. Samples from the six experimental diets were also taken to determine proximate and FA compositions. All samples were kept at $-20^{\circ} \mathrm{C}$ until further analysis.

\section{Lipid extraction and fatty acid analyses}

Total lipids of tissues and diet samples were extracted by homogenisation in $20 \mathrm{vol}$. of chloroform-methanol (2:1, $\mathrm{v} / \mathrm{v})$ containing butylated hydroxytoluene $(0.01 \%, \mathrm{w} / \mathrm{w})$ as an antioxidant ${ }^{(38)}$. FA methyl esters were prepared from total lipid by acid-catalysed transesterification using $2 \mathrm{ml}$ of $1 \% \mathrm{H}_{2} \mathrm{SO}_{4}$ in methanol plus $1 \mathrm{ml}$ toluene, as described by Christie ${ }^{(39)}$, and FA methyl ester extraction and purification, as described by Tocher \& Harvie ${ }^{(40)}$. FA methyl esters were separated and quantified by GLC (Carlo Erba Vega 8160; Carlo Erba Instrumentazone, Milan, Italy) using a $30 \mathrm{~m} \times \times 0.32 \mathrm{~mm}$ capillary column (CP wax 52CB; Chrompak Limited, London, UK). The carrier gas was $\mathrm{H}_{2}$, and the temperature programming used was from 50 to $150^{\circ} \mathrm{C}$ at $40^{\circ} \mathrm{C} / \mathrm{min}$ and then to $225^{\circ} \mathrm{C}$ at $2^{\circ} \mathrm{C} / \mathrm{min}$. Individual methyl esters were identified by comparison with known standards and by reference to published data ${ }^{(41)}$

In the case of PL FA composition of the pyloric caeca, a PL fraction was prepared from $0.5 \mathrm{mg}$ of total lipid applied to a $20 \times 20 \mathrm{~cm}$ silica gel 60 TLC plate (VWR, Lutterworth, UK) and developed in isohexane-diethyl ether-acetic acid (80:20:1, by vol.) and dried for a few minutes at room temperature. The plate was sprayed lightly with 2,7dichlorofluorescein $(0 \cdot 1 \%, \mathrm{w} / \mathrm{v})$ in $97 \%$ methanol $(\mathrm{v} / \mathrm{v})$, and the PL bands on the origin were scraped from the plate and placed in a $15 \mathrm{ml}$ test-tube. FA methyl esters were prepared by acid-catalysed transesterification in $2 \mathrm{ml}$ of $1 \% \mathrm{H}_{2} \mathrm{SO}_{4}$ in methanol at $50^{\circ} \mathrm{C}$ overnight $^{(39)}$. The samples were neutralised with $2.5 \mathrm{ml}$ of $2 \% \mathrm{KHCO}_{3}$ and extracted with $5 \mathrm{ml}$ isohexane-diethyl ether $(1: 1, \mathrm{v} / \mathrm{v})$ plus butylated hydroxytoluene. The samples were then re-extracted with $5 \mathrm{ml}$ isohexane-diethyl ether (1:1), and the combined extracts were dried and dissolved in $0.3 \mathrm{ml}$ of isohexane before FA analysis.

\section{Peroxisomal $\beta$-oxidation capacity}

Liver and red and white muscle were weighed and homogenised in $20 \%(\mathrm{w} / \mathrm{v})$ ice-cold buffered sucrose solution containing $0.25 \mathrm{M}$-sucrose, $0.04 \mathrm{M}$-potassium phosphate buffer ( $\mathrm{pH} 7 \cdot 4$ ), $0 \cdot 15 \mathrm{M}-\mathrm{KCl}, 40 \mathrm{~mm}-\mathrm{KF}$ and $1 \mathrm{~mm}-\mathrm{N}$-acetyl cysteine. The resulting total homogenates were then centrifuged at $1880 \mathrm{~g}$ for $10 \mathrm{~min}$ at $2^{\circ} \mathrm{C}$. The resulting post-nuclear fractions were collected, and portions were used immediately to determine $\beta$-oxidation capacity. The latter was determined as acid-soluble products using radiolabelled $\left[1-{ }^{14} \mathrm{C}\right]$ palmitoyl-CoA as a substrate as described by Frøyland et al. ${ }^{(42)}$.

Briefly, $250 \mu \mathrm{l}$ of the assay medium were added to $2 \mathrm{ml}$ Eppendorf tubes. Then, $10 \mu \mathrm{l}$ of the $\left[1-{ }^{14} \mathrm{C}\right]$ palmitoyl-CoA substrate $(0 \cdot 1 \mu \mathrm{Ci} / 100 \mu \mathrm{M})$ were added to each tube. The samples were pre-incubated at room temperature for $2 \mathrm{~min}$. The reaction was started by the addition of the homogenate $(30-50 \mu \mathrm{l}$ for liver and red muscle and $300-500 \mu \mathrm{l}$ for white muscle, homogenised in $20 \%(\mathrm{w} / \mathrm{v})$ ice-cold buffered sucrose solution as described above), and the reaction continued for $10 \mathrm{~min}$. The reaction was stopped by the addition of $150 \mu \mathrm{l}$ of $1.5 \mathrm{M}-\mathrm{KOH}$. Then, $25 \mu \mathrm{l}$ of FA-free bovine serum albumin $(100 \mathrm{mg} / \mathrm{ml})$ were added, the tubes were vortexed and $500 \mu \mathrm{l}$ of ice-cold $4 \mathrm{~m}$-perchloric acid were added. The tubes were centrifuged at $1880 \mathrm{~g}$ for $10 \mathrm{~min}$. Aliquots of $500 \mu \mathrm{l}$ were placed in scintillation vials, $2.5 \mathrm{ml}$ of the scintillant were added and radioactivity was determined in a scintillation counter. The protein content of the samples was determined according to the Lowry $\operatorname{method}^{(43)}$.

\section{Calculations and statistical analysis}

The following formulae were applied to the data:

$$
\begin{aligned}
& \text { FCR }=\text { feed intake }(g) / \text { wet-weight gain }(g) . \\
& \text { Specific growth rate }(\% / d)=100 \times\left(\ln W_{1}-\ln W_{0}\right) / d,
\end{aligned}
$$

\section{Thermal growth coefficient $(\times 1000)$}

$$
=1000 \times\left(\left(W_{1}\right)^{1 / 3}-\left(W_{0}\right)^{1 / 3}\right) /\left(\mathrm{d} \times \text { temperature }\left({ }^{\circ} \mathrm{C}\right)\right),
$$

$$
\begin{aligned}
& \text { Protein productive value (PPV, g protein gain/ } \\
& \text { g protein ingested }) \\
& \quad=\left(\left(P_{1} W_{1}-P_{0} W_{0}\right) /\left(P_{\mathrm{F}} \times \text { cumulative feed intake }\right)\right)
\end{aligned}
$$

where $W_{0}$ and $W_{1}$ are the initial and final fish mean weights in g; $P_{0}$ and $P_{1}$ are the initial and final protein concentrations of the fish; $P_{\mathrm{F}}$ is the protein concentration of the feed on a DM basis, and cumulative feed intake was determined in grams on a DM basis.

Factorial (two-way) ANOVA was used to analyse the effects of the protein:fat ratio (protein level), dietary RO inclusion (oil source) and their interactions on FA composition of tissues and $\beta$-oxidation. When the interaction of the two factors was significant, multiple comparison testing was performed for both factors to investigate the simple main effects, i.e. the main effect of one factor at a given level of the other, while the main effects were not taken into account ${ }^{(43)}$. Data, which were identified as nonhomogeneous (Levene's test), were subjected to square root, log or arcsine transformation before analysis. Differences were regarded as significant when $P<0.05^{(44)}$ All data are presented as means and standard deviations 
( $n$ 3), and all statistical analyses were performed using SPSS 14.0 (2005; SPSS, Inc., Chicago, IL, USA). The graphs were created using Prism 4 (Graphpad Software, Inc., San Diego, CA, USA).

\section{Results}

\section{Diet proximate and fatty acid composition}

The analysed protein:lipid contents of the diets were $349 \mathrm{~g} / \mathrm{kg}$ protein and $350 \mathrm{~g} / \mathrm{kg}$ lipid for $\mathrm{HP}, 333 \mathrm{~g} / \mathrm{kg}$ protein and $358 \mathrm{~g} / \mathrm{kg}$ lipid for MP, and $293 \mathrm{~g} / \mathrm{kg}$ protein and $384 \mathrm{~g} / \mathrm{kg}$ lipid for LP (Table 1). The digestible protein: digestible energy ratio was $14.5,13.5$ and 12.3 for the HP, MP and LP diets, respectively; digestible protein and digestible energy were calculated using the apparent digestibity coefficient values for protein and energy found in this trial $^{(37)}$. The diets contained either $100 \% \mathrm{FO}$ or a blend of $40 \% \mathrm{FO}$ and $60 \% \mathrm{RO}$, with a consequential effect on the total lipid FA profiles (Table 2). Briefly, the FO diets contained approximately 36\% total SFA, largely 16:0 (approximately 20\%), except for the HP-FO diet which had a slightly higher total SFA content $(40 \cdot 4 \%)$. The total monoenes were $26 \%$, predominantly $18: 1 n-9$ and $16: 1 n-7$. The total $n$-6 PUFA were low $(4.5 \%)$, half of which was $18: 2 n-6$. Lastly, the total $n$-3 PUFA were as high as $32 \%$, mainly as EPA and DHA (18.5 and 8\%, respectively). The $60 \%$ inclusion of RO resulted in the reduction of $16: 0$, and consequently of the total SFA, by half, compared with the FO diets. The total monoenes almost doubled, largely due to the high amount of 18:1n-9 (38.5\%). The total $n$-6 PUFA in the RO diets increased threefold, up to $14 \%$, mainly as $18: 2 n-6$ (13\% of total FA). EPA decreased by $70 \%$ and DHA by more than half (values were 6 and $3 \%$, respectively), and hence the total $n$-3 PUFA were reduced by half $(17 \%)$. The $n-3: n-6$ PUFA ratio was 7 and $1 \cdot 2$ for the FO and RO diets, respectively.

\section{Growth}

At the beginning of the trial, fish had a mean weight of $2053 \mathrm{~g}$. At the end of the trial, all groups showed good performance, mean weight ranging from $3340 \cdot 2$ to $3664.2 \mathrm{~g}$, for HP-RO and MP-RO, respectively (Table 3). The oil source had a significant effect (two-way ANOVA; $P<0.05)$ on growth; specifically, fish fed the RO diets had higher final weight, specific growth rate and thermal growth coefficient compared with fish fed the FO diets. There was no significant effect due to the protein level, and no significant interactions were shown. FCR was not affected by any of the factors and varied from 0.99 to $1 \cdot 10$. Lastly, PPV was significantly affected by both factors. The LP diets had significantly a higher PPV than the other two groups (0.41, 0.43 and 0.47 for HP, MP and LP, respectively), while the RO groups had a higher PPV

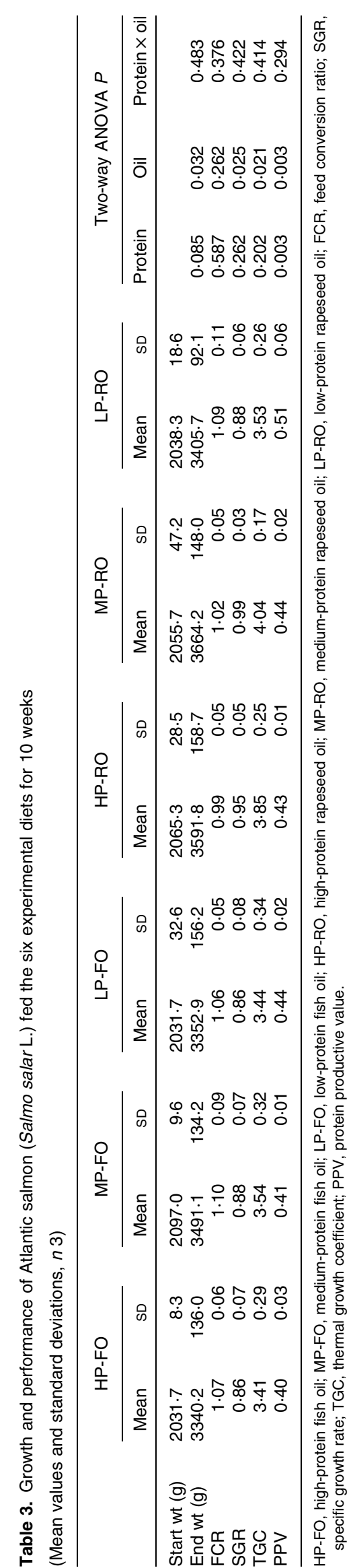


Table 4. Total lipid (mg lipid/g tissue) and fatty acid compositions ( $\mathrm{g} / 100 \mathrm{~g}$ total fatty acids) of muscle from Atlantic salmon (Salmo salar L.) fed the experimental diets for $10 \mathrm{weeks}$ (Mean values and standard deviations, $n 3$ )

\begin{tabular}{|c|c|c|c|c|c|c|c|c|c|c|c|c|c|c|c|}
\hline & \multicolumn{2}{|c|}{ HP-FO } & \multicolumn{2}{|c|}{ MP-FO } & \multicolumn{2}{|c|}{ LP-FO } & \multicolumn{2}{|c|}{ HP-RO } & \multicolumn{2}{|c|}{ MP-RO } & \multicolumn{2}{|c|}{ LP-RO } & \multicolumn{3}{|c|}{ Two-way ANOVA $P$} \\
\hline & Mean & SD & Mean & SD & Mean & SD & Mean & SD & Mean & SD & Mean & SD & Protein & Oil & Protein $\times$ oil \\
\hline Total lipid (mg lipid/g tissue) & $142 \cdot 1$ & $14 \cdot 2$ & $142 \cdot 2$ & $24 \cdot 5$ & $138 \cdot 0$ & $9 \cdot 7$ & $147 \cdot 5$ & $13 \cdot 3$ & $156 \cdot 5$ & $14 \cdot 1$ & $143 \cdot 8$ & $3 \cdot 8$ & 0.621 & 0.242 & 0.843 \\
\hline \multicolumn{16}{|l|}{ Fatty acids } \\
\hline $14: 0$ & 5.8 & 1.3 & $5 \cdot 6$ & 0.4 & $5 \cdot 7$ & 0.3 & 3.4 & $0 \cdot 1$ & $3 \cdot 2$ & 0.1 & $3 \cdot 4$ & 0.3 & 0.766 & 0.000 & 0.988 \\
\hline $16: 0$ & 17.4 & 2.9 & $16 \cdot 3$ & $1 \cdot 3$ & $17 \cdot 0$ & 1.5 & $12 \cdot 4$ & 0.4 & 11.9 & 0.2 & $12 \cdot 3$ & 0.7 & 0.677 & 0.000 & 0.941 \\
\hline $18: 0$ & 4.0 & 0.7 & $3 \cdot 7$ & 0.4 & 3.8 & 0.4 & $3 \cdot 1$ & $0 \cdot 1$ & $3 \cdot 1$ & 0.0 & $3 \cdot 1$ & 0.2 & 0.695 & 0.001 & 0.903 \\
\hline Total saturates ${ }^{*}$ & 28.6 & 4.8 & $26 \cdot 9$ & $2 \cdot 7$ & $28 \cdot 3$ & $3 \cdot 0$ & $20 \cdot 5$ & $1 \cdot 6$ & $19 \cdot 7$ & $1 \cdot 1$ & $20 \cdot 5$ & $2 \cdot 1$ & 0.705 & 0.000 & 0.957 \\
\hline $16: 1 n-7$ & $6 \cdot 9$ & 0.4 & $7 \cdot 3$ & 0.2 & $7 \cdot 1$ & 0.3 & $4 \cdot 3$ & 0.1 & 4.0 & 0.1 & $4 \cdot 2$ & 0.1 & 0.977 & 0.000 & 0.106 \\
\hline $18: 1 n-9$ & $21 \cdot 3$ & 0.6 & $21 \cdot 3$ & 0.9 & $20 \cdot 2$ & $1 \cdot 1$ & $33 \cdot 7$ & 1.5 & $36 \cdot 3$ & 1.4 & $35 \cdot 3$ & 0.7 & $0 \cdot 131$ & 0.000 & 0.090 \\
\hline $18: 1 n-7$ & 3.6 & 0.1 & 3.8 & 0.3 & 3.8 & 0.3 & 3.4 & 0.4 & 3.0 & 0.2 & $3 \cdot 4$ & 0.1 & 0.427 & 0.004 & 0.214 \\
\hline $20: 1 n-9$ & $2 \cdot 7$ & 0.1 & $2 \cdot 8$ & $0 \cdot 0$ & $2 \cdot 5$ & 0.2 & $2 \cdot 9$ & 0.2 & 3.0 & 0.1 & $2 \cdot 8$ & 0.1 & 0.033 & 0.004 & 0.632 \\
\hline $22: 1$ & $2 \cdot 5$ & 0.2 & 2.5 & 0.2 & $2 \cdot 2$ & 0.2 & $2 \cdot 1$ & 0.2 & $2 \cdot 0$ & 0.2 & $2 \cdot 0$ & 0.2 & 0.147 & 0.001 & 0.489 \\
\hline $24: 1 n-9$ & 0.5 & 0.1 & 0.6 & 0.1 & 0.5 & 0.1 & 0.4 & $0 \cdot 1$ & 0.4 & 0.0 & 0.5 & 0.2 & 0.571 & 0.425 & 0.216 \\
\hline Total monoenes $\dagger$ & 37.7 & 0.4 & 38.6 & 0.6 & $36 \cdot 7$ & 1.7 & $47 \cdot 1$ & 1.9 & $49 \cdot 0$ & 1.5 & $48 \cdot 4$ & $1 \cdot 0$ & $0 \cdot 190$ & 0.000 & 0.336 \\
\hline $18: 2 n-6$ & $6 \cdot 8$ & 0.6 & 6.5 & 0.4 & $6 \cdot 6$ & 0.0 & $11 \cdot 3$ & $0 \cdot 1$ & 11.7 & 0.2 & $11 \cdot 8$ & 0.4 & 0.862 & 0.000 & 0.177 \\
\hline $20: 2 n-6$ & 0.4 & 0.1 & 0.4 & 0.0 & 0.4 & 0.0 & 0.6 & 0.0 & 0.7 & 0.0 & 0.6 & 0.1 & $0 \cdot 194$ & 0.000 & 0.484 \\
\hline $20: 3 n-6$ & 0.2 & 0.0 & 0.3 & 0.0 & 0.2 & 0.0 & 0.2 & 0.0 & 0.2 & 0.0 & 0.2 & 0.0 & 0.224 & 0.000 & 0.308 \\
\hline $20: 4 n-6$ & 0.7 & 0.1 & 0.8 & $0 \cdot 1$ & 0.7 & $0 \cdot 1$ & 0.4 & 0.0 & 0.4 & 0.0 & 0.4 & 0.0 & 0.875 & 0.000 & 0.476 \\
\hline Total $n-6 \ddagger$ & 8.5 & 0.8 & 8.4 & 0.3 & 8.3 & 0.1 & $12 \cdot 8$ & 0.2 & $13 \cdot 2$ & 0.2 & $13 \cdot 3$ & 0.5 & 0.797 & 0.000 & 0.379 \\
\hline $18: 3 n-3$ & $2 \cdot 1$ & 0.3 & $2 \cdot 0$ & 0.2 & $2 \cdot 0$ & 0.0 & 4.6 & 0.1 & 4.7 & 0.1 & 4.6 & 0.3 & 0.924 & 0.000 & 0.637 \\
\hline $18: 4 n-3$ & $1 \cdot 3$ & 0.1 & 1.4 & $0 \cdot 1$ & 1.4 & $0 \cdot 1$ & 0.8 & 0.0 & 0.8 & 0.0 & 0.8 & 0.1 & 0.855 & 0.000 & 0.475 \\
\hline $20: 4 n-3$ & 1.0 & 0.1 & 1.0 & 0.1 & $1 \cdot 0$ & 0.1 & 0.7 & 0.0 & 0.7 & 0.0 & 0.7 & 0.0 & 0.746 & 0.000 & 0.419 \\
\hline $20: 5 n-3$ & 9.9 & 1.6 & $10 \cdot 6$ & 1.2 & 10.7 & 0.9 & $5 \cdot 7$ & 0.3 & 5.0 & 0.1 & $5 \cdot 0$ & 0.6 & 0.996 & 0.000 & 0.338 \\
\hline $22: 5 n-3$ & $3 \cdot 1$ & 0.5 & $3 \cdot 3$ & 0.2 & 3.5 & 0.2 & $2 \cdot 1$ & 0.2 & $1 \cdot 8$ & 0.1 & 1.8 & 0.2 & 0.924 & 0.000 & 0.184 \\
\hline $22: 6 n-3$ & $7 \cdot 6$ & 1.5 & $7 \cdot 7$ & $1 \cdot 0$ & 8.0 & $0 \cdot 6$ & 5.4 & 0.5 & 4.8 & 0.4 & 4.7 & 0.8 & 0.924 & 0.000 & 0.574 \\
\hline Total $n$-3 PUFA§ & $25 \cdot 2$ & 3.8 & $26 \cdot 1$ & $2 \cdot 7$ & $26 \cdot 7$ & 1.9 & $19 \cdot 6$ & $1 \cdot 2$ & $18 \cdot 1$ & 0.6 & $17 \cdot 8$ & 1.9 & 0.981 & 0.000 & 0.451 \\
\hline Total PUFA & 33.7 & 4.4 & 34.5 & $2 \cdot 9$ & $35 \cdot 0$ & $2 \cdot 0$ & 32.4 & 1.4 & $31 \cdot 3$ & 0.7 & $31 \cdot 1$ & $2 \cdot 4$ & 0.996 & 0.039 & 0.680 \\
\hline$n-3: n-6$ & $2 \cdot 9$ & 0.3 & $3 \cdot 1$ & 0.2 & $3 \cdot 2$ & 0.2 & 1.5 & 0.1 & 1.4 & 0.0 & 1.3 & 0.1 & 0.761 & 0.000 & 0.049 \\
\hline
\end{tabular}


compared with the FO groups $(0.42 v \cdot 0.46$ for $\mathrm{FO}$ and $\mathrm{RO}$, respectively). These results are described in detail in Karalazos et al. ${ }^{(37)}$.

\section{Tissue fatty acid compositions}

The total lipid content and the FA composition of muscle and liver from fish fed the six experimental diets for 10 weeks are shown in Tables 4 and 5, respectively. The muscle total lipid varied from 138.0 to $156.5 \mathrm{mg} \mathrm{lipid} / \mathrm{g}$ tissue. The liver lipid content was much lower, compared with that of muscle, ranging from 50.1 to $64.9 \mathrm{mg}$ lipid/g tissue. Neither the dietary protein level nor the $\mathrm{RO}$ inclusion affected the muscle and liver lipid contents, and no significant interactions were shown by twoway ANOVA.

Regarding the FA composition of muscle and liver, they were significantly affected by the RO but not by the protein level, and no significant interactions between the two factors were shown. Specifically, the inclusion of RO resulted in a significant increase of $18: 1 n-9$, total monoenes, $18: 2 n-6,20: 2 n-6$, total $n-6$ PUFA and $18: 3 n-3$. On the other hand, all saturates, including total SFA, 16:1n-7, $22: 1$, arachidonic acid, EPA, DHA, total $n-3$ FA and the $n-3: n-6$ ratio, were significantly reduced when the fish were fed the diets containing RO.

Notably in muscle, EPA was reduced by half (10.4 $v$. $5 \cdot 2 \%$ for the FO $v$. RO, respectively), while the reduction in DHA was more moderate $(7 \cdot 8 v .5 \cdot 0 \%$ for FO $v$. RO, respectively). $18: 1 n-9$ increased from 20.9 to $35 \cdot 1 \%$, $18: 2 n-6$ from $6 \cdot 6$ to $11.6 \%$ and $18: 3 n-3$ from $2 \cdot 0$ to $4.6 \%$ for the FO and RO groups, respectively. Similarly in the liver, EPA was reduced from 16.0 to $9.9 \%$ and DHA from $16 \cdot 2$ to $13 \cdot 2 \%$ for the $\mathrm{FO}$ and $\mathrm{RO}$ groups, respectively. The increase between the $\mathrm{FO}$ and $\mathrm{RO}$ groups for $18: 1 n-9,18: 2 n-6$ and $18: 3 n-3$ was $13 \cdot 8 v .27 \cdot 9 \%, 1.9 v$. $7 \cdot 6 \%$ and 0.5 v. $2.9 \%$, respectively.

The differences $(\Delta)$ between diet and muscle FA concentrations for the six experimental diets are shown in Table 6, where negative $\Delta$ values indicate lower values in muscle compared with the diet, whereas positive values indicate accumulation in tissues relative to the diet. Thus, the SFA, arachidonic acid, EPA and the total $n$ - 3 PUFA were utilised to a higher extent by the fish fed the FO diets

Table 5. Total lipid (mg lipid/g tissue) and fatty acid compositions ( $\mathrm{g} / 100 \mathrm{~g}$ total fatty acids) of liver from Atlantic salmon (Salmo salar L.) fed the experimental diets for 10 weeks

(Mean values and standard deviations, $n$ 3)

\begin{tabular}{|c|c|c|c|c|c|c|c|c|c|c|c|c|c|c|c|}
\hline & \multicolumn{2}{|c|}{ HP-FO } & \multicolumn{2}{|c|}{ MP-FO } & \multicolumn{2}{|c|}{ LP-FO } & \multicolumn{2}{|c|}{ HP-RO } & \multicolumn{2}{|c|}{ MP-RO } & \multicolumn{2}{|c|}{ LP-RO } & \multicolumn{3}{|c|}{ Two-way ANOVA $P$} \\
\hline & Mean & SD & Mean & SD & Mean & SD & Mean & SD & Mean & SD & Mean & SD & Protein & Oil & Protein $\times$ oil \\
\hline $\begin{array}{l}\text { Total lipid (mg lipid/g } \\
\text { tissue) }\end{array}$ & $61 \cdot 4$ & $5 \cdot 1$ & 64.9 & $7 \cdot 1$ & $53 \cdot 8$ & $8 \cdot 1$ & $60 \cdot 7$ & 3.3 & 54.9 & $11 \cdot 0$ & $50 \cdot 1$ & $5 \cdot 8$ & 0.094 & 0.182 & 0.535 \\
\hline \multicolumn{16}{|l|}{ Fatty acids } \\
\hline $14: 0$ & $2 \cdot 7$ & 0.8 & $2 \cdot 8$ & 0.7 & $2 \cdot 7$ & 0.7 & 1.5 & 0.3 & 1.3 & 0.3 & 1.4 & 0.3 & 0.997 & 0.000 & 0.907 \\
\hline $16: 0$ & $14 \cdot 2$ & $1 \cdot 1$ & $14 \cdot 3$ & 1.8 & $15 \cdot 6$ & 1.0 & $10 \cdot 5$ & 0.5 & 11.5 & 1.3 & $12 \cdot 0$ & $1 \cdot 1$ & 0.144 & 0.000 & 0.759 \\
\hline $18: 0$ & 7.9 & 0.3 & $7 \cdot 6$ & 1.0 & $7 \cdot 7$ & 0.9 & $5 \cdot 2$ & 0.2 & $5 \cdot 6$ & 0.6 & $5 \cdot 3$ & 0.5 & 0.955 & 0.000 & 0.705 \\
\hline Total saturates* & $25 \cdot 5$ & 1.7 & $25 \cdot 9$ & $2 \cdot 6$ & $26 \cdot 9$ & $2 \cdot 2$ & $18 \cdot 2$ & 0.8 & $19 \cdot 6$ & $2 \cdot 0$ & $20 \cdot 2$ & 1.6 & 0.355 & 0.000 & 0.899 \\
\hline $16: 1 n-7$ & 4.6 & 0.6 & 4.9 & 0.6 & 4.4 & 0.7 & $2 \cdot 4$ & 0.0 & 1.9 & 0.2 & 2.0 & 0.2 & 0.467 & 0.000 & 0.269 \\
\hline $18: 1 n-9$ & 14.8 & 1.0 & 14.5 & 1.4 & $12 \cdot 0$ & 1.4 & 29.8 & $2 \cdot 6$ & $26 \cdot 9$ & 4.5 & $27 \cdot 1$ & 4.0 & 0.038 & 0.000 & 0.106 \\
\hline $18: 1 n-7$ & 4.3 & 0.1 & 4.4 & 0.3 & 3.9 & 0.2 & $3 \cdot 3$ & 0.3 & $2 \cdot 7$ & 0.4 & $3 \cdot 0$ & 0.2 & 0.148 & 0.000 & 0.103 \\
\hline $20: 1 n-9$ & $2 \cdot 2$ & 0.1 & $2 \cdot 1$ & 0.2 & 1.6 & 0.2 & 3.8 & 0.2 & 3.6 & 0.3 & $3 \cdot 1$ & 0.3 & 0.001 & 0.000 & 0.776 \\
\hline $22: 1$ & 0.9 & 0.1 & 0.8 & 0.1 & 0.8 & 0.1 & 0.7 & 0.1 & 0.5 & $0 \cdot 1$ & 0.5 & 0.1 & 0.033 & 0.000 & 0.442 \\
\hline $24: 1 n-9$ & 0.6 & 0.1 & 0.7 & 0.2 & 0.6 & 0.1 & 0.5 & 0.0 & 0.5 & 0.1 & 0.6 & 0.1 & 0.834 & 0.164 & 0.739 \\
\hline Total monoenes $\dagger$ & $27 \cdot 7$ & 1.3 & $27 \cdot 7$ & 2.4 & 23.5 & $2 \cdot 4$ & $40 \cdot 7$ & $2 \cdot 8$ & $36 \cdot 3$ & $5 \cdot 1$ & $36 \cdot 3$ & 4.5 & 0.125 & 0.000 & 0.467 \\
\hline $18: 2 n-6$ & 1.9 & 0.2 & 1.9 & 0.2 & 1.9 & 0.3 & 7.6 & 0.3 & $7 \cdot 2$ & 0.7 & $8 \cdot 2$ & 0.7 & 0.298 & 0.000 & 0.355 \\
\hline $20: 2 n-6$ & 0.4 & 0.0 & 0.4 & 0.0 & 0.4 & 0.1 & 1.7 & 0.0 & 1.9 & 0.1 & $1 \cdot 7$ & 0.2 & 0.203 & 0.000 & 0.299 \\
\hline $20: 3 n-6$ & 0.3 & 0.0 & 0.3 & 0.0 & 0.3 & 0.0 & 0.3 & 0.0 & 0.3 & 0.0 & 0.3 & 0.0 & 0.954 & 0.082 & 0.598 \\
\hline $20: 4 n-6$ & $2 \cdot 7$ & 0.2 & $2 \cdot 4$ & 0.3 & 3.0 & 0.3 & 1.7 & 0.3 & $2 \cdot 0$ & 0.5 & $2 \cdot 1$ & 0.5 & 0.196 & 0.001 & 0.329 \\
\hline Total $n-6 \ddagger$ & 5.9 & 0.3 & 5.7 & 0.1 & $6 \cdot 3$ & 0.1 & 11.8 & 0.0 & 11.8 & $0 \cdot 1$ & $12 \cdot 6$ & 0.3 & 0.000 & 0.000 & 0.162 \\
\hline $18: 3 n-3$ & 0.5 & 0.0 & 0.6 & 0.1 & 0.5 & 0.1 & $2 \cdot 9$ & 0.1 & $2 \cdot 7$ & 0.4 & $3 \cdot 1$ & 0.3 & 0.391 & 0.000 & 0.352 \\
\hline $18: 4 n-3$ & 0.4 & 0.0 & 0.4 & 0.1 & 0.4 & 0.1 & 0.2 & 0.0 & 0.1 & 0.0 & 0.1 & 0.0 & 0.614 & 0.000 & 0.651 \\
\hline $20: 4 n-3$ & $1 \cdot 3$ & 0.1 & 1.5 & 0.2 & $1 \cdot 3$ & 0.2 & 0.8 & 0.0 & 0.7 & 0.0 & $0 \cdot 8$ & 0.0 & 0.897 & 0.000 & 0.132 \\
\hline $20: 5 n-3$ & $15 \cdot 3$ & $1 \cdot 1$ & $15 \cdot 6$ & 0.2 & $17 \cdot 2$ & 0.9 & 9.1 & 0.9 & $10 \cdot 5$ & $1 \cdot 3$ & $10 \cdot 1$ & $1 \cdot 1$ & 0.068 & 0.000 & 0.236 \\
\hline $22: 5 n-3$ & $6 \cdot 9$ & 0.4 & $7 \cdot 7$ & 1.1 & $6 \cdot 6$ & 0.6 & 3.3 & 0.1 & $3 \cdot 2$ & 0.2 & $3 \cdot 0$ & 0.1 & 0.033 & 0.000 & 0.364 \\
\hline $22: 6 n-3$ & $16 \cdot 3$ & $1 \cdot 1$ & $15 \cdot 0$ & $1 \cdot 2$ & $17 \cdot 2$ & 1.5 & $12 \cdot 3$ & $1 \cdot 3$ & $14 \cdot 2$ & $2 \cdot 2$ & $13 \cdot 0$ & $2 \cdot 4$ & 0.738 & 0.003 & 0.199 \\
\hline Total $n-3$ PUFA§ & 40.9 & 1.6 & $40 \cdot 8$ & 0.3 & 43.3 & 0.2 & 29.3 & $2 \cdot 1$ & $32 \cdot 3$ & $3 \cdot 2$ & 30.9 & $3 \cdot 2$ & 0.120 & 0.000 & 0.114 \\
\hline Total PUFA & $46 \cdot 8$ & 1.8 & $46 \cdot 5$ & 0.2 & $49 \cdot 6$ & 0.2 & $41 \cdot 1$ & $2 \cdot 0$ & $44 \cdot 1$ & $3 \cdot 1$ & 43.5 & $3 \cdot 2$ & 0.141 & 0.000 & 0.293 \\
\hline$n-3: n-6$ & $7 \cdot 0$ & 0.4 & $7 \cdot 2$ & 0.1 & 6.9 & 0.1 & 2.5 & 0.2 & $2 \cdot 7$ & 0.3 & 2.5 & 0.3 & 0.155 & 0.000 & 0.967 \\
\hline
\end{tabular}

HP-FO, high-protein fish oil; MP-FO, medium-protein fish oil; LP-FO, low-protein fish oil; HP-RO, high-protein rapeseed oil; MP-RO, medium-protein rapeseed oil; LP-RO, low-protein rapeseed oil.

* Includes 15:0, 20:0 and 22:0.

† Includes 16:1n-9 and $20: 1 n-7$.

¥Includes 18:3n-6, $22: 4 n-6$ and $22: 5 n-6$.

$\S$ Includes $20: 3 n-3$ and $22: 4 n-3$. 
Table 6. Differences $(\Delta)^{\star}$ between diet and muscle fatty acid concentrations $(\mathrm{g} / 100 \mathrm{~g}$ total fatty acids) for the six experimental treatments

\begin{tabular}{lrrrrrr}
\hline & HP-FO & MP-FO & LP-FO & HP-RO & MP-RO & LP-RO \\
\hline Fatty acids & & & & & & \\
$14: 0$ & -3.0 & -2.9 & -2.6 & 0.0 & 0.1 & 0.6 \\
$16: 0$ & -5.8 & -3.9 & -3.2 & 0.3 & 1.0 & 2.1 \\
$18: 0$ & -1.9 & -1.3 & -1.2 & -0.6 & -1.2 & -0.4 \\
Total saturates $\dagger$ & -11.8 & -9.0 & -7.4 & -1.4 & -1.9 & 1.4 \\
$16: 1 n-7$ & -1.1 & -1.5 & -1.6 & 1.0 & 0.9 & 1.2 \\
$18: 1 n-9$ & 11.7 & 10.4 & 8.9 & -4.0 & -1.4 & -4.7 \\
Total monoenes $\neq$ & 13.0 & 11.7 & 9.7 & -0.8 & 1.9 & -0.7 \\
$18: 2 n-6$ & 4.7 & 4.1 & 3.9 & -1.2 & -1.2 & -2.0 \\
$20: 4 n-6$ & -0.4 & -0.4 & -0.4 & 0.0 & -0.1 & 0.0 \\
Total $n-6 \S$ & 4.4 & 3.8 & 3.5 & -0.4 & -0.8 & -1.5 \\
$18: 3 n-3$ & 1.5 & 1.3 & 1.2 & -1.6 & -1.6 & -2.1 \\
$20: 5 n-3$ & -7.7 & -8.4 & -8.1 & -0.1 & -1.0 & -0.8 \\
$22: 6 n-3$ & -0.4 & -0.2 & 0.1 & 2.2 & 1.6 & 1.8 \\
Total $n-3 \|$ & -5.6 & -6.6 & -5.8 & 2.7 & 0.8 & 0.7 \\
\hline
\end{tabular}

HP-FO, high-protein fish oil; MP-FO, medium-protein fish oil; LP-FO, low-protein fish oil; HP-RO, highprotein rapeseed oil; MP-RO, medium-protein rapeseed oil; LP-RO, low-protein rapeseed oil.

* Negative $\Delta$ values indicate lower values in muscle compared with the diet, whereas positive values indicate accumulation in muscle relative to the diet.

†Includes 15:0,20:0 and 22:0.

$\ddagger$ Includes $16: 1 n-9,18: 1 n-7,20: 1 n-9,20: 1 n-7,22: 1$ and $24: 1 n-9$.

$\S$ Includes 18:3n-6, $20: 2 n-6,20: 3 n-6,22: 4 n-6$ and $22: 5 n-6$.

|| Includes 18:4n-3, 20:3n-3, 20:4n-3, 22:4n-3 and $22: 5 n-3$

compared with the RO groups. DHA appeared to be slightly utilised in the FO groups, but was accumulated in the muscle in the RO groups. On the contrary, $18: 1 n-9$, $18: 2 n-6$ and $18: 3 n-3$ were found in higher concentrations in the muscle in the FO groups but were utilised in the RO groups. Likewise, the differences $(\Delta)$ between diet and liver FA concentrations for the six experimental diets are shown in Table 7. In the liver, the 14:0 and 16:0 were utilised in all groups, although lower $\Delta$ values were found in the FO groups. Similar to the muscle, 18:1n-9, $18: 2 n-6$ and $18: 3 n-3$ in the liver were much more utilised in the RO groups compared with the FO ones. Lastly, 18:0, arachidonic acid and DHA were accumulated in the liver in all groups.

\section{Pyloric caeca phospholipid fatty acid composition}

Pyloric caeca PL FA composition (Table 8) was significantly affected mainly by the dietary oil source, although in some cases, a significant main effect due to the protein level and/ or significant interactions between the two factors were also shown (two-way ANOVA; $P<0 \cdot 05$ ). Pyloric caeca PL comprised almost half as $n$-3 PUFA (41.6-49.9\%), mainly DHA and EPA, followed by SFA (24.3-30.5\%), largely

Table 7. Differences $(\Delta)^{*}$ between diet and liver fatty acid concentrations $(\mathrm{g} / 100 \mathrm{~g}$ total fatty acids) for the six experimental treatments

\begin{tabular}{|c|c|c|c|c|c|c|}
\hline & HP-FO & MP-FO & LP-FO & HP-RO & MP-RO & LP-RO \\
\hline \multicolumn{7}{|l|}{ Fatty acids } \\
\hline $14: 0$ & $-6 \cdot 2$ & $-5 \cdot 7$ & -5.6 & -1.9 & $-1 \cdot 7$ & -1.4 \\
\hline $16: 0$ & $-9 \cdot 0$ & $-6 \cdot 0$ & $-4 \cdot 6$ & $-1 \cdot 6$ & 0.6 & $1 \cdot 7$ \\
\hline $18: 0$ & $2 \cdot 0$ & 2.7 & $2 \cdot 8$ & 1.5 & $1 \cdot 3$ & $1 \cdot 7$ \\
\hline Total saturates† & -14.9 & $-10 \cdot 0$ & $-8 \cdot 8$ & $-3 \cdot 7$ & $-2 \cdot 0$ & $1 \cdot 1$ \\
\hline $16: 1 n-7$ & $-4 \cdot 1$ & -3.9 & $-4 \cdot 3$ & $-1 \cdot 1$ & -1.5 & -1.3 \\
\hline $18: 1 n-9$ & 5.3 & 3.6 & 0.7 & -7.9 & $-10 \cdot 8$ & $-13 \cdot 0$ \\
\hline Total monoenesł & 3.0 & 0.8 & -3.5 & $-7 \cdot 2$ & $-10 \cdot 8$ & $-12 \cdot 8$ \\
\hline $18: 2 n-6$ & -0.3 & -0.5 & -0.7 & -4.9 & $-5 \cdot 8$ & $-5 \cdot 7$ \\
\hline $20: 4 n-6$ & 1.6 & 1.3 & 1.9 & 1.3 & 1.6 & 1.7 \\
\hline Total $n-6 \S$ & 1.8 & $1 \cdot 1$ & 1.5 & -1.5 & $-2 \cdot 2$ & $-2 \cdot 2$ \\
\hline $18: 3 n-3$ & -0.1 & -0.2 & -0.3 & $-3 \cdot 3$ & -3.5 & $-3 \cdot 6$ \\
\hline $20: 5 n-3$ & $-2 \cdot 2$ & $-3 \cdot 4$ & $-1 \cdot 7$ & 3.3 & 4.5 & 4.3 \\
\hline $22: 6 n-3$ & 8.3 & $7 \cdot 0$ & 9.3 & 9.1 & $10 \cdot 9$ & $10 \cdot 1$ \\
\hline Total $n-3 \|$ & $10 \cdot 1$ & $8 \cdot 1$ & $10 \cdot 9$ & $12 \cdot 4$ & $15 \cdot 0$ & $13 \cdot 8$ \\
\hline
\end{tabular}

HP-FO, high-protein fish oil; MP-FO, medium-protein fish oil; LP-FO, low-protein fish oil; HP-RO, highprotein rapeseed oil; MP-RO, medium-protein rapeseed oil; LP-RO, low-protein rapeseed oil.

* Negative $\Delta$ values indicate lower values in liver compared with diet, whereas positive values indicate

accumulation in liver relative to diet.

† Includes 15:0, 20:0 and 22:0.

$\ddagger$ Includes $16: 1 n-9,18: 1 n-7,20: 1 n-9,20: 1 n-7,22: 1$ and $24: 1 n-9$.

§Includes 18:3n-6, 20:2n-6, 20:3n-6, 22:4n-6 and $22: 5 n-6$.

II Includes 18:4n-3, 20:3n-3, 20:4n-3, 22:4n-3 and $22: 5 n-3$. 
Table 8. Fatty acid compositions ( $\mathrm{g} / 100 \mathrm{~g}$ total fatty acids) of total phospholipids of the pyloric caeca from Atlantic salmon (Salmo salar $\mathrm{L}$.) fed the experimental diets for 10 weeks

(Mean values and standard deviations, $n 3$ )

\begin{tabular}{|c|c|c|c|c|c|c|c|c|c|c|c|c|c|c|c|}
\hline & \multicolumn{2}{|c|}{ HP-FO } & \multicolumn{2}{|c|}{ MP-FO } & \multicolumn{2}{|c|}{ LP-FO } & \multicolumn{2}{|c|}{ HP-RO } & \multicolumn{2}{|c|}{ MP-RO } & \multicolumn{2}{|c|}{ LP-RO } & \multicolumn{3}{|c|}{ Two-way ANOVA $P$} \\
\hline & Mean & SD & Mean & SD & Mean & SD & Mean & SD & Mean & SD & Mean & SD & Protein & Oil & Protein $\times$ oil \\
\hline \multicolumn{16}{|l|}{ Fatty acids } \\
\hline $14: 0$ & $2 \cdot 4$ & 0.1 & $2 \cdot 3$ & 0.1 & $2 \cdot 4$ & 0.2 & 1.2 & 0.1 & 1.2 & 0.3 & $1 \cdot 1$ & 0.1 & 0.808 & 0.000 & 0.698 \\
\hline $16: 0$ & 20.5 & 0.3 & 21.0 & 0.3 & 20.9 & 0.5 & $16 \cdot 7$ & 0.3 & $17 \cdot 1$ & 0.8 & $16 \cdot 9$ & 0.4 & 0.340 & 0.000 & 0.946 \\
\hline $18: 0$ & $6 \cdot 1$ & 0.2 & 6.7 & 0.5 & $6 \cdot 4$ & 0.6 & 5.9 & 0.4 & $6 \cdot 3$ & 0.1 & 6.7 & 0.2 & 0.037 & 0.480 & 0.327 \\
\hline Total saturates* & 29.5 & 0.4 & 30.5 & 0.8 & $30 \cdot 3$ & 0.8 & $24 \cdot 3$ & 0.2 & $25 \cdot 2$ & $1 \cdot 1$ & 25.4 & 0.9 & 0.079 & 0.000 & 0.847 \\
\hline $16: 1 n-7$ & 2.9 & 0.1 & 2.9 & 0.3 & 3.0 & 0.3 & $1 \cdot 3$ & 0.0 & 1.3 & 0.2 & $1 \cdot 2$ & 0.1 & 0.902 & 0.000 & 0.548 \\
\hline $18: 1 n-9$ & $6 \cdot 2$ & 0.4 & $6 \cdot 2$ & 0.2 & $6 \cdot 2$ & 0.3 & $14 \cdot 6$ & 0.6 & $15 \cdot 2$ & 0.4 & 16.5 & 0.3 & 0.006 & 0.000 & 0.004 \\
\hline $18: 1 n-7$ & 3.5 & 0.1 & 3.5 & 0.1 & 3.6 & 0.1 & 2.9 & 0.1 & 2.9 & 0.2 & 3.4 & 0.2 & 0.002 & 0.000 & 0.006 \\
\hline $20: 1 n-9$ & 0.8 & 0.1 & 0.8 & 0.1 & 0.7 & 0.0 & 1.4 & 0.2 & 1.5 & 0.1 & 1.3 & 0.2 & 0.134 & 0.000 & 0.790 \\
\hline $22: 1$ & 0.2 & 0.1 & 0.2 & 0.1 & 0.2 & 0.0 & 0.2 & 0.2 & 0.4 & 0.3 & 0.1 & 0.1 & 0.231 & 0.785 & 0.659 \\
\hline $24: 1 n-9$ & $1 \cdot 1$ & 0.1 & 1.0 & 0.1 & 0.9 & 0.1 & 1.0 & 0.1 & 1.0 & 0.0 & 1.0 & 0.1 & 0.394 & 0.682 & 0.375 \\
\hline Total monoenes $\dagger$ & $15 \cdot 2$ & 0.5 & $15 \cdot 0$ & 0.7 & $15 \cdot 0$ & 0.6 & 21.9 & 1.0 & $22 \cdot 6$ & $1 \cdot 2$ & $24 \cdot 0$ & 0.7 & 0.162 & 0.000 & 0.076 \\
\hline $18: 2 n-6$ & 1.1 & 0.1 & 1.1 & 0.1 & 1.3 & 0.2 & 4.6 & 0.1 & 4.6 & 0.2 & $5 \cdot 2$ & 0.2 & 0.000 & 0.000 & 0.008 \\
\hline $20: 2 n-6$ & 0.2 & 0.0 & 0.2 & 0.0 & 0.2 & 0.0 & 0.9 & 0.1 & 0.9 & 0.2 & 0.8 & 0.1 & 0.481 & 0.000 & 0.550 \\
\hline $20: 3 n-6$ & 0.2 & 0.0 & 0.2 & 0.0 & 0.2 & 0.0 & 0.4 & 0.0 & 0.3 & 0.1 & 0.3 & 0.0 & 0.022 & 0.000 & 0.046 \\
\hline $20: 4 n-6$ & 3.0 & 0.2 & 2.8 & 0.1 & 3.0 & 0.2 & $2 \cdot 2$ & 0.1 & $2 \cdot 1$ & 0.1 & $2 \cdot 0$ & 0.1 & 0.487 & 0.000 & 0.321 \\
\hline $22: 5 n-6$ & 0.6 & 0.0 & 0.6 & 0.0 & 0.6 & 0.0 & 0.5 & 0.0 & 0.5 & 0.0 & 0.5 & 0.0 & 0.109 & 0.000 & 0.854 \\
\hline Total $n-6 \neq$ & $5 \cdot 4$ & 0.2 & $5 \cdot 3$ & 0.1 & 5.5 & 0.0 & $8 \cdot 8$ & 0.2 & 8.5 & 0.4 & 9.0 & 0.2 & 0.049 & 0.000 & 0.612 \\
\hline $18: 3 n-3$ & 0.3 & 0.0 & 0.3 & 0.0 & 0.3 & 0.0 & 1.9 & 0.0 & 1.8 & 0.1 & $2 \cdot 0$ & 0.1 & 0.008 & 0.000 & 0.054 \\
\hline $18: 4 n-3$ & 0.3 & 0.0 & 0.3 & 0.1 & 0.3 & 0.1 & 0.2 & 0.0 & 0.2 & 0.0 & 0.2 & 0.0 & 0.911 & 0.000 & 0.827 \\
\hline $20: 4 n-3$ & 0.4 & 0.0 & 0.4 & 0.0 & 0.4 & 0.0 & 0.5 & 0.0 & 0.4 & 0.0 & 0.4 & 0.0 & 0.010 & 0.424 & 0.417 \\
\hline $20: 5 n-3$ & $19 \cdot 3$ & 0.6 & 20.7 & 0.2 & $22 \cdot 1$ & 0.2 & $16 \cdot 1$ & 1.1 & $16 \cdot 1$ & 0.3 & $16 \cdot 7$ & 1.0 & 0.004 & 0.000 & 0.041 \\
\hline $22: 5 n-3$ & $3 \cdot 8$ & 0.2 & 3.7 & 0.1 & 3.5 & 0.3 & 3.5 & 0.1 & 3.6 & 0.1 & $3 \cdot 2$ & 0.1 & 0.003 & 0.024 & 0.464 \\
\hline $22: 6 n-3$ & $25 \cdot 8$ & 0.7 & $23 \cdot 8$ & 0.9 & $22 \cdot 7$ & 0.6 & $22 \cdot 6$ & 0.1 & $21 \cdot 3$ & 1.4 & 18.9 & 0.2 & 0.000 & 0.000 & 0.384 \\
\hline Total $n$-3 PUFA§ & 49.9 & 0.9 & $49 \cdot 2$ & 0.9 & $49 \cdot 3$ & 0.6 & $45 \cdot 0$ & $1 \cdot 2$ & 43.7 & 1.9 & 41.6 & 1.2 & 0.034 & 0.000 & 0.129 \\
\hline Total PUFA & 55.3 & 0.8 & 54.4 & 0.9 & 54.8 & 0.6 & $53 \cdot 8$ & 1.1 & $52 \cdot 2$ & $2 \cdot 3$ & 50.6 & 1.2 & 0.071 & 0.001 & 0.216 \\
\hline$n-3: n-6$ & $9 \cdot 2$ & 0.5 & 9.4 & 0.2 & 9.0 & 0.1 & $5 \cdot 1$ & 0.2 & $5 \cdot 1$ & 0.1 & 4.6 & 0.1 & 0.014 & 0.000 & 0.666 \\
\hline
\end{tabular}

HP-FO, high-protein fish oil; MP-FO, medium-protein fish oil; LP-FO, low-protein fish oil; HP-RO, high-protein rapeseed oil; MP-RO, medium-protein rapeseed oil; LP-RO, low-protein rapeseed oil.

${ }^{*}$ Includes 15:0, 20:0 and 22:0.

† Includes $16: 1 n-9$ and $20: 1 n-7$

Includes $18: 3 n-6$ and $22: 4 n-6$.

$\S$ Includes $20: 3 n-3$ and $22: 4 n-3$.

16: 0 , and monoenes (15.0-24.0\%), while $n$-6 PUFA were less than 9\% (5.3-9.0\%). DHA was the most abundant FA varying from 18.9 to $25.8 \%$ and being affected significantly both by the oil source $(\mathrm{FO}>\mathrm{RO})$ and by the protein content (reduced with lower protein content). EPA was also found at high levels (16.1-22.1\%) and was affected significantly by both factors, while significant interactions were also found. As shown in Fig. 1, the RO groups had a significantly lower EPA content at all protein levels, whereas EPA content was significantly higher for the LP diet compared with the HP diet but only when FO was the oil source. Regarding total SFA, there was a significant effect due to the oil source $(\mathrm{FO}>\mathrm{RO})$, and the same pattern was shown for 16:0. Total monoenes, and mainly 18:1n-9, were significantly increased due to the dietary inclusion of RO. However, significant interactions were found for $18: 1 n-9$, showing an effect of protein content (higher 18:1n-9 level for the LP diet $v$. HP and MP) only for the RO diets. Total $n$-6 FA, mainly $18: 2 n-6$, were increased in fish fed the RO diet, while arachidonic acid was decreased. Noticeably, all $n-6$ FA were at relatively low levels. Significant interactions were shown for $18: 2 n-6$, resulting in a significantly higher content in fish fed LP diets compared with HP and MP for the RO diets.

\section{Peroxisomal $\beta$-oxidation capacity}

The peroxisomal palmitoyl-CoA oxidation capacity in the liver, red and white muscle is shown in Table 9. The peroxisomal $\beta$-oxidation capacity in the liver ranged from 6.6 to $12.5 \mathrm{pmol} / \mathrm{min}$ per $\mathrm{mg}$ protein, in red muscle from 26.7 to $36.3 \mathrm{pmol} / \mathrm{min}$ per $\mathrm{mg}$ protein and in white muscle from 1.1 to $1.6 \mathrm{pmol} / \mathrm{min}$ per $\mathrm{mg}$ protein. In the liver and red muscle, $\beta$-oxidation capacity was significantly affected by the oil source $(P=0.035$ and 0.034 for the liver and red muscle, respectively). Specifically, RO inclusion resulted in significantly higher $\beta$-oxidation in both the liver ( $7.2 v .9 .7$ for $\mathrm{FO}$ and $\mathrm{RO}$, respectively) and red muscle ( $28.2 v .33 .7$ for $\mathrm{FO}$ and $\mathrm{RO}$, respectively). However, in white muscle, there was a significant interaction of the two factors (protein level and oil source), and hence the simple main effects of the two factors were tested, as demonstrated in Fig. 2. Specifically, the HP group had a significantly higher $\beta$-oxidation capacity than MP and LP when FO was the oil source, whereas in contrast, the $\beta$-oxidation capacity in HP was lower than the other two groups when RO was included in the diet. Regarding the effects of the oil source on $\beta$-oxidation capacity at the three protein levels, the ranking was 

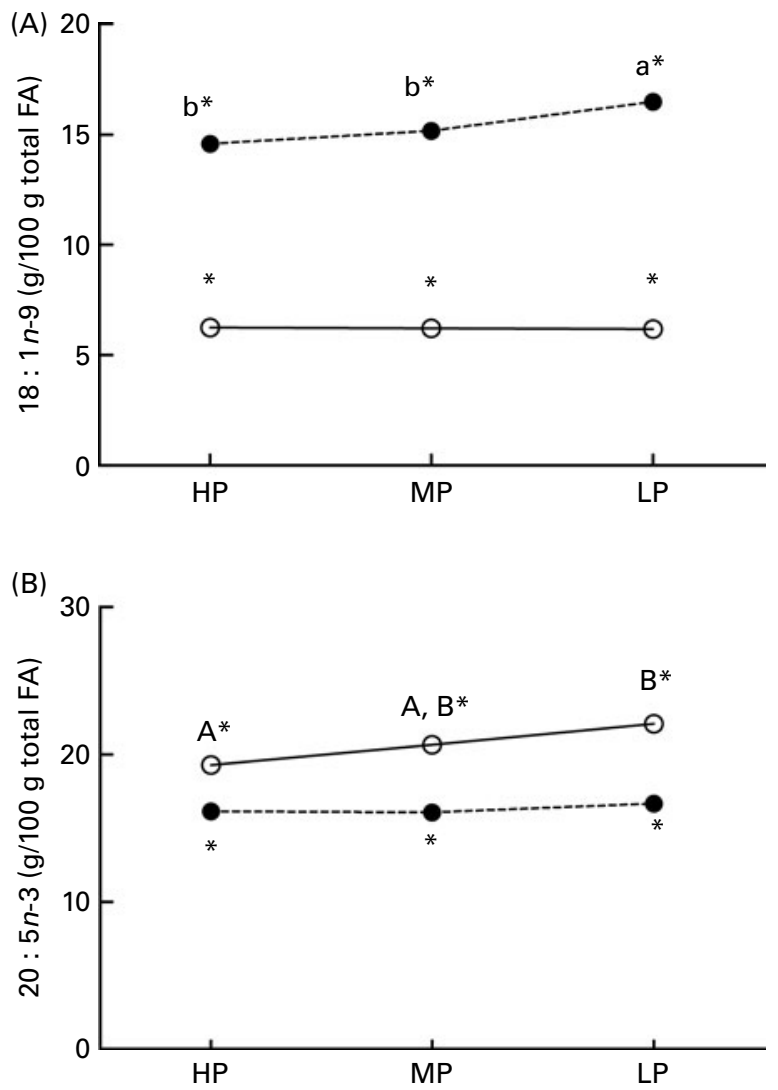

Fig. 1. Means of $18: 1 n-9$ (A) and $20: 5 n-3$ (B) (g/100 g total fatty acids (FA)) of total phospholipids of pyloric caeca from Atlantic salmon (Salmo salar L.) fed the six experimental diets, in a two-way ANOVA, showing the effects of the two factors and their interaction. ${ }^{a, b}$ Mean values with unlike letters were significantly different $(P<0.05)$ for each oil source: A,B fish oil (FO; $O$ ); a,b rapeseed oil $(\mathrm{RO} ; \bullet)$, respectively. ${ }^{*}$ Mean values were significantly different $(P<0.05)$ between the $\mathrm{FO}$ and RO values within each protein level. $\mathrm{HP}$, high protein; MP, medium protein; LP, low protein.

$\mathrm{FO}>\mathrm{RO}$ for $\mathrm{HP}, \mathrm{RO}>\mathrm{FO}$ for $\mathrm{MP}$, while $\mathrm{FO}$ and $\mathrm{RO}$ did not significantly differ at LP.

\section{Discussion}

\section{Growth}

The effects and interactions of the two factors on growth are thoroughly discussed in Karalazos et al. ${ }^{(37)}$. Briefly, it was shown that, in agreement with previous studies ${ }^{(23,30-34)}$, no negative effects on growth and FCR were observed when the fish were fed with low-protein/high-lipid diets, even at protein levels below $300 \mathrm{~g} / \mathrm{kg}$. This is much lower than what had been previously tested and of significant importance regarding the tolerance in low-protein diets and the utilisation of lipid for energy. Moreover, the dietary inclusion of RO at the expense of FO had a positive effect on final weight, specific growth rate and thermal growth coefficient. Such an effect had been reported by a couple of studies ${ }^{(23,24)}$ and possibly relates to the positive effect of low- $n-3$ FA diets towards higher growth for large salmon ${ }^{(21,45)}$. This effect is probably explained by the higher digestibility of RO, and other VO, FA, and hence better utilisation of the dietary oil for energy by the fish. This theory is confirmed by the digestibility results of the present study ${ }^{(37)}$. Moreover, the increased $\beta$-oxidation and the changes in the pyloric caeca PL discussed below could also have played a significant role.

Lastly, a positive effect of increased dietary lipid content on protein retention and, hence, on protein sparing has been previously reported ${ }^{(23,24,32,33)}$ and was also confirmed in the present study as the LP diets showed a higher PPV. The inclusion of $\mathrm{RO}$ at the expense of $\mathrm{FO}$ resulted in a positive effect on PPV also. The potential effects of dietary $\mathrm{VO}$ in protein sparing in fish are largely unknown; however, the results of the present study are supported by the increased $\beta$-oxidation capacity that was shown in tissues of Atlantic salmon fed with the RO diets compared with the FO diets. The results showing increased catabolism of FA for energy production may suggest a protein-sparing effect. The $\beta$-oxidation results are discussed further below.

\section{Tissue fatty acid composition}

Tissue total lipid FA composition reflects the FA composition of the diet, usually following linear correlations between the concentrations of individual FA in the diet and the tissues $(16,17,19,21,24,46,47)$. The results of the present study are in agreement with previous studies, showing a reduction in SFA, $16: 1 n-7,20: 4 n-6$, EPA, DHA and $n-3: n-6$ ratio, respective to the reductions in the dietary FA, with inclusion of RO. Similarly, the increase of $18: 1 n-9,18: 2 n-6$ and $18: 3 n-3$ in the diets containing $\mathrm{RO}$, compared with the FO diets, was reflected in muscle

Table 9. Peroxisomal $\beta$-oxidation capacity (pmol/min per mg protein) of liver, red and white muscle from Atlantic salmon (Salmo salar L.) fed the experimental diets for 10 weeks

(Mean values and standard deviations, $n 3$ )

\begin{tabular}{|c|c|c|c|c|c|c|c|c|c|c|c|c|c|c|c|}
\hline & \multicolumn{2}{|c|}{ HP-FO } & \multicolumn{2}{|c|}{ MP-FO } & \multicolumn{2}{|c|}{ LP-FO } & \multicolumn{2}{|c|}{ HP-RO } & \multicolumn{2}{|c|}{ MP-RO } & \multicolumn{2}{|c|}{ LP-RO } & \multicolumn{3}{|c|}{ Two-way ANOVA $P$} \\
\hline & Mean & SD & Mean & SD & Mean & SD & Mean & SD & Mean & SD & Mean & SD & Protein & Oil & Protein $\times$ oil \\
\hline Liver & $7 \cdot 2$ & $2 \cdot 6$ & $6 \cdot 6$ & 0.9 & $7 \cdot 7$ & 1.8 & $7 \cdot 8$ & 1.1 & 8.7 & 3.7 & 12.5 & 1.9 & 0.121 & 0.035 & 0.288 \\
\hline Red muscle & 30.0 & 2.6 & $28 \cdot 0$ & 2.6 & $26 \cdot 7$ & 4.6 & $36 \cdot 3$ & 8.2 & $31 \cdot 2$ & 4.4 & 33.6 & 4.5 & 0.430 & 0.034 & 0.796 \\
\hline White muscle & 1.6 & 0.1 & 1.2 & 0.1 & 1.3 & 0.0 & $1 \cdot 1$ & 0.1 & 1.6 & 0.0 & 1.4 & 0.2 & 0.908 & 0.719 & 0.000 \\
\hline
\end{tabular}

HP-FO, high-protein fish oil; MP-FO, medium-protein fish oil; LP-FO, low-protein fish oil; HP-RO, high-protein rapeseed oil; MP-RO, medium-protein rapeseed oil; LP-RO, low-protein rapeseed oil. 


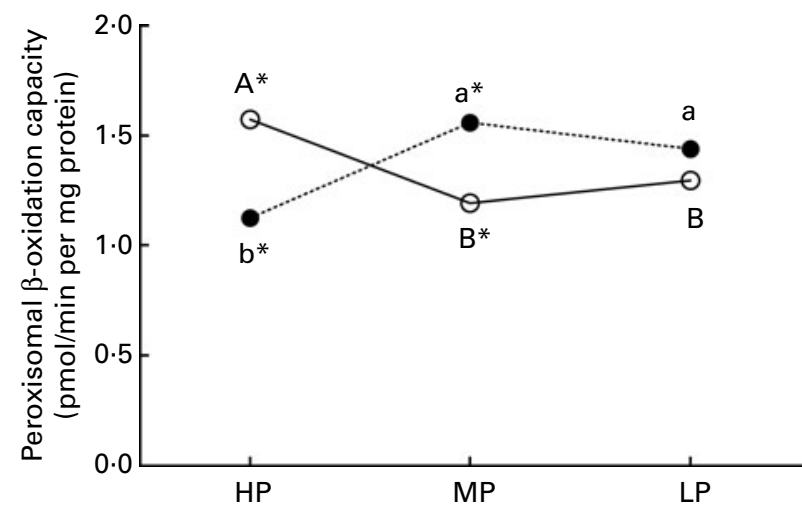

Fig. 2. Means of the peroxisomal $\beta$-oxidation capacity (pmol/min per mg protein) of white muscle from Atlantic salmon fed the six experimental diets, in a two-way ANOVA, showing the effects of the two factors and their interaction. a,b Mean values with unlike letters were significantly different for each oil source; $\mathrm{A}, \mathrm{B}$, fish oil (FO; O); a,b, rapeseed oil (RO; $\bullet$ ), respectively. * Mean values were significantly different $(P<0.05)$ between the $\mathrm{FO}$ and $\mathrm{RO}$ values within each protein level. HP, high protein; MP, medium protein; LP, low protein.

and liver FA. It is clear that, since the FA compositions of the diets were affected by the oil source only, the changes in the muscle and liver FA compositions were also due to the dietary RO inclusion and, as expected, the dietary protein level had no significant effect on the tissue FA composition.

The changes in muscle and liver FA indicate selective utilisation or retention of individual FA. It has been shown previously that when specific FA are in abundance in the diet, they are selectively utilised for energy production, via $\beta$-oxidation, and perhaps to a lesser extent for desaturation and elongation. In contrast, when FA, and especially $n-3$ highly unsaturated FA, are limited in the diet, they are retained or deposited in the tissues $^{(16,17,19)}$. For example, in the present study, 18:1n-9 was increased almost fourfold, 18:2n-6 more than fivefold and $18: 3 n-3$ ninefold in the diets when FO was replaced with RO; however, the respective increases in muscle were less than or about twofold for all of the above FA, while in the liver, it was approximately twofold for $18: 1 n-9$, less than fourfold for $18: 2 n-6$ and less than sixfold for $18: 3 n-3$, indicating selective utilisation of these FA in the RO groups. On the other hand, although the reduction in EPA and DHA was more than 60\% in the RO diets, the decrease in muscle was approximately $50 \%$ for EPA and 35\% for DHA, while in the liver, the reduction was approximately $35 \%$ for EPA and $20 \%$ for DHA, indicating a selective retention of these FA in the tissues when the dietary supply was reduced. These results are also supported by the $\Delta$ values for muscle and liver, i.e. the differences between diet and tissue FA concentrations. It was shown that, when provided at high concentrations, $18: 1 n-9,18: 2 n-6$ and $18: n-3$ were highly utilised in both muscle and liver, and EPA and DHA were accumulated in the tissues when dietary supply was reduced. In other animals, the selective retention of essential FA in specific tissues is believed to occur by a mechanism of reacylation of $s n$-2-monoacylglycerols by hepatic microsomal activity of monoacylglycerol acyltransferase, during lipolysis ${ }^{(48)}$. However, the moderate reductions in EPA and DHA shown in the present study may also be partially affected by the enhanced endogenous desaturation and elongation of dietary $18: 3 n-3^{(49-51)}$.

Furthermore, it is noteworthy that the results of the present trial suggest that the inclusion of RO up to $60 \%$, at the expense of $\mathrm{FO}$, in diets of Atlantic salmon at various dietary protein:lipid levels caused only moderate reductions in tissue EPA and DHA. This was also shown by Karalazos et $a l^{(24)}$, where fish were reared at low water temperatures. Reductions in $n$ - 3 highly unsaturated FA affect the quality of the final product, compromise its high nutritional value for the human consumer and should be avoided ${ }^{(13)}$. Hence, such results, leading to moderate reductions in EPA and DHA, are promising for the use of VO in commercial diets, although the present trial was conducted over a short time period, which could have masked the full extent of the FA changes that could occur over the whole production cycle of salmon.

\section{Pyloric caeca phospholipid fatty acid composition}

PL are of importance in lipid digestion in fish, playing a significant role in the structure of cell membranes of lipoproteins for the transport of lipids in the blood and lymph and also in forming intra-luminal mixed micelles along with bile salts and dietary lipids ${ }^{(52)}$. PL in fish contain mainly $16: 0$ and $18: 1 n-9$ at the $s n-1$ position and $20: 5 n-3$ and $22: 6 n-3$ at the $s n-2$ position ${ }^{(26)}$. Hence, the intestinal PL FA composition and the consequent alterations occurring due to dietary FA changes may affect the uptake and digestibility of lipids and ultimately the utilisation of diets, especially when high-lipid diets are used. Pyloric caeca are major sites in the intestine duct for nutrient uptake and the most significant section for lipid uptake after their digestion ${ }^{(53)}$. In the present study, focus was given to the interactive effects of the protein:lipid level and oil source in the FA composition of the pyloric caeca.

In the present study, it was shown that, regardless of the dietary treatment, $n-3$ PUFA were the major FA group in pyloric caeca PL, consisting mainly of DHA and EPA, followed by SFA, largely $16: 0$, and monoenes (15.0-24.0\%), while $n$-6 PUFA were less than $9(5 \cdot 3-9 \cdot 0) \%$, which is in accordance with previous reports ${ }^{(26)}$. The high abundance of these FA could have also been enhanced by their high recovery rate into enterocyte $\mathrm{PL}^{(54,55)}$.

However, the dietary changes had significant effects on the PL FA, mainly due to the oil source but also due to the protein:lipid level, although to a small extent, while significant interactions were also observed. Specifically, the dietary inclusion of $\mathrm{RO}$ at the expense of $\mathrm{FO}$ resulted in significant reductions in DHA, EPA, 16:0 and 20:4n-6, and significant increases of $18: 1 n-9$ and $18: 2 n-6$. On the other hand, the effect of the protein content was also 
significant in some cases with contradicting results, including 18:0 (HP < LP) and DHA (HP > LP). Lastly, significant interactions of the two factors were also revealed by two-way ANOVA for some FA, including 18:1n-9 and $18: 2 n-6$, with a significant increase due to the protein content $(\mathrm{HP}>\mathrm{LP}$ ) only for the RO groups, while EPA had a significant decrease due to the protein content $(\mathrm{HP}<\mathrm{LP})$ only for the FO groups (for these FA, the effect of the oil source was significant at all protein:lipid levels). These changes reflected the changes in the dietary FA compositions, similar to the muscle and liver total lipid FA compositions, although to a relatively smaller extent. However, altering the relative proportions of FA in intestinal PL, as an effect of the use of $\mathrm{VO}$ in the diets and more interestingly of the protein:lipid level or the interactive effects of the two factors, is most likely to affect their structure and consequently their role in the digestion and uptake of lipids and nutrients. The present study showed that lipid digestibility was improved due to $\mathrm{RO}$ inclusion but also (for FO only) due to low-protein/high-lipid diets (data presented and discussed in Karalazos et al $\left.{ }^{(37)}\right)$. However, the clarification of the exact mechanisms involved requires further investigation.

\section{Peroxisomal $\beta$-oxidation capacity}

The peroxisomal $\beta$-oxidation activity was measured in liver, red and white muscle. Conducting the assay onsite was not possible, and hence the samples of tissues had to be frozen on dry ice and transferred to the Institute of Aquaculture in Scotland where analysis took place. Therefore, the measurement of the total $\beta$-oxidation activity was not possible, and the results obtained represent the peroxisomal $\beta$-oxidation capacity. Previous studies in Atlantic salmon have shown that different tissues/organs have very different $\beta$-oxidation capacities as a result of their unique and different energy requirements, depending on their functions ${ }^{(56-61)}$. In agreement with that, between the three tissues assessed in the present study, red muscle had the highest $\beta$-oxidation activity and white muscle the lowest. However, it should be noted that the $\beta$-oxidation capacities of these tissues, and the consequent ranking, were expressed on a tissue protein content basis. Considering that white muscle accounts for more than $60 \%$ of the total body mass of Atlantic salmon, it becomes clear that its role in energy production for the fish is the most significant ${ }^{(56,57)}$.

It is well documented that tissue $\beta$-oxidation capacities are affected by various factors, including the diet and especially the dietary FA composition ${ }^{(51,57,58,61,62)}$. Specific FA, such as $16: 0,18: 1 n-9,22: 1 n-11$ and $20: 1 n-9$, are readily catabolised, although $18: 3 n-3,18: 2 n-6$ and even EPA and DHA are also good substrates for $\beta$-oxidation, especially when provided at high levels ${ }^{(57,60,63)}$. Hence, dietary changes, incorporating VO, could affect the $\beta$-oxidation capacities of tissues. However, the results of previous studies are contradictory. Tocher et al. ${ }^{(51)}$ showed that $\beta$-oxidation capacity was not affected either by the oil content or by the oil type in diets of Atlantic salmon. On the contrary, Stubhaug et al. ${ }^{(57)}$ reported that dietary RO inclusion had a positive effect on $\beta$-oxidation. The results of the present study showed a significant increase in liver and red muscle $\beta$-oxidation capacities due to RO inclusion. This could explain, at least partially, the better performance that was shown for the RO groups and the enhanced protein-sparing effect. However, it remains unclear whether this was primarily due to changes in dietary FA composition rather than due to other dietary factors. For instance, an interactive effect of the protein level and the oil source was shown in white muscle, suggesting a higher $\beta$-oxidation capacity for the FO groups than the RO ones at the HP level, whereas the RO groups had higher values for the other two protein levels, although the difference was significant only for the MP diet. The higher $\beta$-oxidation capacity of the HP-FO group could be due to the higher content of SFA in that diet; although if the hypothesis is correct, it remains unclear why such an effect was not reflected in the other two tissues.

\section{Conclusions}

In conclusion, the investigation of the interactive effects of the dietary protein:lipid level and FO replacement showed that low-protein/high-lipid diets can be used safely in large Atlantic salmon nutrition with regard to the growth and FCR, while the inclusion of $\mathrm{RO}$ at the expense of FO can enhance the growth of the fish by increased protein sparing and $\beta$-oxidation. In terms of the tissue FA compositions, they were significantly affected by the RO inclusion, reflecting the FA composition of the diets. However, the reduction in EPA and DHA, resulting from the dietary FA changes, was only moderate, and hence the impact on the final product quality, in terms of the nutritional value for the human consumer, was limited. Further studies on the longer-term use of diets are therefore warranted.

\section{Acknowledgements}

The present study was carried out with support from BioMar AS. V. K. was supported by the State Scholarships Foundation (IKY), Greece. V. K. wrote the manuscript with assistance from all other authors, especially J. G. B. and E. A. B.; E. А. B. was responsible for all aspects of the feeding trial, with assistance from V. K. in sample collection. V. K. was responsible for all aspects of analysis, with assistance and technical advice for $\beta$-oxidation analysis from J. R. D. and D. R. T. All authors read and approved the findings of the study. None of the authors had a conflict of interest. 


\section{References}

1. Sargent JR \& Tacon AG (1999) Development of farmed fish: a nutritionally necessary alternative to meat. Proc Nutr Soc 58, $377-383$.

2. Hertrampf JW \& Piedad-Pascual F (2000) Handbook on Ingredients for Aquaculture Feeds. Dordrecht: Kluwer Academic Publishers.

3. NRC (1993) Nutrient Requirements of Fish. Washington, DC: National Academy Press.

4. Pike IH \& Barlow SM (2003) Impact of fish farming on fish stocks. Int Aquafeed Dir Buy Guide 24-29.

5. Tacon AGJ (2004) Use of fish meal and fish oil in aquaculture: a global perspective. Aquat Resour Cult Dev 1, 3-14.

6. Tidwell JH \& Allan GL (2001) Fish as food: aquaculture's contribution. Ecological and economic impacts and contributions of fish farming and capture fisheries. EMBO Rep $\mathbf{2}$, 958-963.

7. Delgado CL, Wada N, Rosegrant MW, et al. (2003) Fish to 2020: Supply and Demand in Changing Global Markets. Washington, DC/Penang: International Food Policy Research Institute/WorldFish Center.

8. Trushenski JT, Kasper CS \& Kohler CC (2006) Challenges and opportunities in finfish nutrition. NAm J Aquac 68, 122-140.

9. Bell JG, McGhee F, Dick JR, et al. (2005) Dioxin and dioxin-like polychlorinated biphenyls (PCBs) in Scottish farmed salmon (Salmo salar): effects of replacement of dietary marine fish oil with vegetable oils. Aquaculture 243, 305-314.

10. SCAN (2000) Dioxin Contamination of Feedingstuffs and their Contribution to the Contamination of Food of Animal Origin. Opinion of the Scientific Committee on Animal Nutrition, adopted on 6 November 2000. Brussels: European Commission for Health and Consumer Protection Directorate General.

11. SCF (2001) Update of the Risk Assessment of Dioxins and Dioxin-like PCBs in Food Based on New Scientific Information Available since Adoption of the SCF Opinion of 22nd November 2000. Opinion of the Scientific Committee on Food, adopted on 30 May 2001. Brussels: European Commission for Health and Consumer Protection Directorate General.

12. Bethune C, Seierstad SL, Seljeflot I, et al. (2006) Dietary intake of differently fed salmon: a preliminary study on contaminants. Eur J Clin Invest 36, 193-201.

13. Bell JG \& Waagbø R (2008) Safe and nutritious aquaculture produce: benefits and risks of alternative sustainable aquafeeds. In Aquaculture in the Ecosystem, pp. 185-225 [M Holmer, K Black, CM Duarte, N Marbà and I Karakassis, editors]. Berlin: Springer.

14. Turchini GM, Torstensen BE \& Ng W-K (2009) Fish oil replacement in finfish nutrition. Rev Aquac 1, 10-57.

15. Glencross BD (2009) Exploring the nutritional demand for essential fatty acids by aquaculture species. Rev Aquac 1, $71-124$.

16. Bell JG, McEvoy J, Tocher DR, et al. (2001) Replacement of fish oil with rapeseed oil in diets of Atlantic salmon (Salmo salar) affects tissue lipid compositions and hepatocyte fatty acid metabolism. J Nutr 131, 1535-1543.

17. Bell JG, McGhee F, Campbell PJ, et al. (2003) Rapeseed oil as an alternative to marine fish oil in diets of post-smolt Atlantic salmon (Salmo salar): changes in flesh fatty acid composition and effectiveness of subsequent fish oil "wash out". Aquaculture 218, 515-528.

18. Ng W-K, Sigholt T \& Bell JG (2004) The influence of environmental temperature on the apparent nutrient and fatty acid digestibility in Atlantic salmon (Salmo salar L.) fed finishing diets containing different blends of fish oil, rapeseed oil and palm oil. Aquacult Res 35, 1228-1237.
19. Torstensen BE, Frøyland L \& Lie $\varnothing$ (2004) Replacing dietary fish oil with increasing levels of rapeseed oil and olive oil effects on Atlantic salmon (Salmo salar L.) tissue and lipoprotein lipid composition and lipogenic enzyme activities. Aquacult Nutr 10, 175-192.

20. Torstensen BE, Frøyland L, Ørnsrud R, et al. (2004) Tailoring of a cardioprotective muscle fatty acid composition of Atlantic salmon (Salmo salar) fed vegetable oils. Food Chem $\mathbf{8 7}$, 567-580.

21. Torstensen BE, Bell JG, Rosenlund G, et al. (2005) Tailoring of Atlantic salmon (Salmo salar L.) flesh lipid composition and sensory quality by replacing fish oil with a vegetable oil blend. J Agric Food Chem 53, 10166-10178.

22. Caballero MJ, Obach A, Rosenlund G, et al. (2002) Impact of different dietary lipid sources on growth, lipid digestibility, tissue fatty acid composition and histology of rainbow trout, Oncorbynchus mykiss. Aquaculture 214, 253-271.

23. Bendiksen EÅ, Berg OK, Jobling M, et al. (2003) Digestibility, growth and nutrient utilisation of Atlantic salmon parr (Salmo salar L.) in relation to temperature, feed fat content and oil source. Aquaculture 224, 283-299.

24. Karalazos V, Bendiksen EA, Dick JR, et al. (2007) Effects of dietary protein, and fat level and rapeseed oil on growth and tissue fatty acid composition and metabolism in Atlantic salmon (Salmo salar L.) reared at low water temperatures. Aquacult Nutr 13, 256-265.

25. Henderson RJ \& Sargent JR (1985) Chain-length specificities of mitochondrial and peroxisimal $\beta$-oxidation of fatty acids in livers of rainbow trout (Salmo gairdneri). Comp Biochem Physiol B 82, 79-85.

26. Sargent JR, Tocher DR \& Bell JG (2002) The lipids. In Fish Nutrition, 3rd ed., pp. 181-257 [JE Halver and RW Hardy, editors]. San Diego, CA: Academic Press, Elsevier Science.

27. Kiessling KH \& Kiessling A (1993) Selective utilization of fatty acids in rainbow trout (Oncorbynchus mykiss Walbaum) red muscle mitochondria. Can J Zool 71, 248-251.

28. Cho CY \& Bureau DP (1997) Reduction of waste output from salmonid aquaculture through feeds and feeding. Prog Fish Cult 59, 155-160.

29. Halver JE \& Hardy RW (2002) Nutrient flow and retention. In Fish Nutrition, 3rd ed., pp. 768-769 [JE Halver and RW Hardy, editors]. San Diego, CA: Academic Press, Elsevier Science.

30. Azevedo PA, Leeson S, Cho CY, et al. (2004) Growth, nitrogen and energy utilization of juveniles from four salmonid species: diet, species and size effects. Aquaculture 234, 393-414.

31. Azevedo PA, Leeson S, Cho CY, et al. (2004) Growth and feed utilization of large size rainbow trout (Oncorbynchus mykiss) and Atlantic salmon (Salmo salar) reared in freshwater: diet and species effects, and responses over time. Aquacult Nutr 10, 401-411.

32. Einen O \& Roem AJ (1997) Dietary protein/energy ratios for Atlantic salmon in relation to fish size: growth, feed utilization and slaughter quality. Aquacult Nutr 3, 115-126.

33. Hillestad M, Johnsen F, Austreng E, et al. (1998) Long-term effects of dietary fat level and feeding rate on growth, feed utilization and carcass quality of Atlantic salmon. Aquacult Nutr 4, 89-97.

34. Solberg C (2004) Influence of dietary oil content on the growth and chemical composition of Atlantic salmon (Salmo salar). Aquacult Nutr 10, 31-37.

35. Bendiksen EA, Arnesen AM \& Jobling M (2003) Effects of dietary fatty acid profile and fat content on smolting and seawater performance in Atlantic salmon (Salmo salar L.). Aquaculture 225, 149-163. 
36. Bendiksen EA \& Jobling M (2003) Effects of temperature and feed composition on essential fatty acid ( $n-3$ and $n-6)$ retention in Atlantic salmon (Salmo salar L.) parr. Fish Physiol Biochem 29, 133-140.

37. Karalazos V, Bendiksen EÅ \& Bell JG (2010) Interactive effects of dietary protein/lipid level and oil source on growth, feed utilisation and nutrient and fatty acid digestibility of Atlantic salmon. Aquaculture (Epublication ahead of print version 24 November 2010).

38. Folch J, Lees M \& Sloane Stanley GH (1957) A simple method for the isolation and purification of total lipides from animal tissues. J Biol Chem 226, 497-509.

39. Christie WW (1982) Lipid Analyses, 2nd ed. Oxford: Pergamon Press.

40. Tocher DR \& Harvie DG (1988) Fatty acid compositions of the major phosphoglycerides from fish neural tissues; $(n-3)$ and $(n-6)$ polyunsaturated fatty acids in rainbow trout (Salmo gairdneri) and cod (Gadus morbua) brains and retinas. Fish Physiol Biochem 5, 229-239.

41. Ackman RG (1980) Fish lipids, part 1. In Advances in Fish Science and Technology, pp. 86-103 [JJ Connell, editor]. Farnham: Fishing New Books Ltd.

42. Frøyland L, Asiedu DK, Vaagenes H, et al. (1995) Tetradecylthioacetic acid incorporated into very low density lipoprotein: changes in the fatty acid composition and reduced plasma lipids in cholesterol-fed hamsters. $J$ Lipid Res 36, 2529-2540.

43. Lowry OH, Rosebrough NJ, Farr AL, et al. (1951) Protein measurement with the folin phenol reagent. $J$ Biol Chem 193, 265-275.

44. Zar JH (1999) Biostatistical Analysis, 4th ed. London: Prentice-Hall International Editions.

45. Menoyo D, Lopez-Bote CJ, Bautista JM, et al. (2003) Growth, digestibility and fatty acid utilization in large Atlantic salmon (Salmo salar) fed varying levels of $n-3$ and saturated fatty acids. Aquaculture 225, 295-307.

46. Bell JG, Tocher DR, Henderson RJ, et al. (2003) Altered fatty acid compositions in Atlantic salmon (Salmo salar) fed diets containing linseed and rapeseed oils can be partially restored by a subsequent fish oil finishing diet. J Nutr 133, $2793-2801$.

47. Rosenlund G, Obach A, Sandberg MG, et al. (2001) Effect of alternative lipid sources on long-term growth performance and quality of Atlantic salmon (Salmo salar L.). Aquacult Res 32, Suppl. 1, 323-328.

48. Xia T, Mostafa N, Bhat BG, et al. (1993) Selective retention of essential fatty acids: the role of hepatic monoacylglycerol acyltransferase. Am J Physiol Regul Integr Comp Physiol 265, R414-R419.

49. Tocher DR, Bell JG, Dick JR, et al. (2003) Effects of dietary vegetable oil on Atlantic salmon hepatocyte fatty acid desaturation and liver fatty acid compositions. Lipids $\mathbf{3 8}$, $723-732$.
50. Tocher DR, Bell JG, MacGlaughlin P, et al. (2001) Hepatocyte fatty acid desaturation and polyunsaturated fatty acid composition of liver in salmonids: effects of dietary vegetable oil. Comp Biochem Physiol B 130, 257-270.

51. Tocher DR, Bell JG, McGhee F, et al. (2003) Effects of dietary lipid level and vegetable oil on fatty acid metabolism in Atlantic salmon (Salmo salar L.) over the whole production cycle. Fish Physiol Biochem 29, 193-209.

52. Tocher DR, Bendiksen EA, Campbell PJ, et al. (2008) The role of phospholipids in nutrition and metabolism of teleost fish. Aquaculture 280, 21-34.

53. Denstadli V, Vegusdal A, Krogdahl A, et al. (2004) Lipid absorption in different segments of the gastrointestinal tract of Atlantic salmon (Salmo salar L.). Aquaculture 240 385-398.

54. Oxley A, Tocher DR, Torstensen BE, et al. (2005) Fatty acid utilisation and metabolism in caecal enterocytes of rainbow trout (Oncorbynchus mykiss) fed dietary fish or copepod oil. Biochim Biophys Acta 1737, 119-129.

55. Pérez JA, Rodríguez C \& Henderson RJ (1999) The uptake and esterification of radiolabelled fatty acids by enterocytes isolated from rainbow trout (Oncorbynchus mykiss). Fish Physiol Biochem 20, 125-134.

56. Frøyland L, Lie O \& Berge RK (2000) Mitochondrial and peroxisomal beta-oxidation capacities in various tissues from Atlantic salmon Salmo salar. Aquacult Nutr 6, 85-89.

57. Stubhaug I, Frøyland L \& Torstensen BE (2005) $\beta$-Oxidation capacity of red and white muscle and liver in Atlantic salmon (Salmo salar L.) - effects of increasing dietary rapeseed oil and olive oil to replace capelin oil. Lipids 40, 39-47.

58. Stubhaug I, Lie $\varnothing$ \& Torstensen BE (2007) Fatty acid productive value and $\beta$-oxidation capacity in Atlantic salmon (Salmo salar L.) fed on different lipid sources along the whole growth period. Aquacult Nutr 13, 145-155.

59. Tocher DR, Fonseca-Madrigal J, Bell JG, et al. (2002) Effects of diets containing linseed oil on fatty acid desaturation and oxidation in hepatocytes and intestinal enterocytes in Atlantic salmon (Salmo salar). Fish Physiol Biochem 26, 157-170.

60. Henderson RJ \& Tocher DR (1987) The lipid composition and biochemistry of freshwater fish. Prog Lipid Res 26, 281-347.

61. Torstensen BE, Lie $\varnothing$ \& Frøyland L (2000) Lipid metabolism and tissue composition in Atlantic salmon (Salmo salar L.) effects of capelin oil, palm oil, and oleic acid-enriched sunflower oil as dietary lipid sources. Lipids 35, 653-664.

62. Torstensen BE \& Stubhaug I (2004) Beta-oxidation of 18:3n-3 in Atlantic salmon (Salmo salar L.) hepatocytes treated with different fatty acids. Lipids 39, 153-160.

63. Stubhaug I, Tocher DR, Bell JG, et al. (2005) Fatty acid metabolism in Atlantic salmon (Salmo salar L.) hepatocytes and influence of dietary vegetable oil. Biochim Biophys Acta 1734, 277-288. 